\title{
FEDERALISMO FISCAL: \\ AS IMPLICAÇÕES DA COMPETÊNCIA ESTADUAL DO ICMS E O PROBLEMA DA GUERRA FISCAL
}

Lívia Maria de Souza Santos

\section{INTRODUÇÃO}

É evidente que a organização do Brasil sob a forma de uma república federativa gera implicações diretas na organização política-administrativa do país, sobretudo no que tange à sua organização tributária.

No que se refere, especificamente, ao sistema tributário nacional ao disciplinar a outorga de competências tributárias, a Constituição Federal de 1988 concedeu aos Estados membros e ao Distrito Federal, a autorização de tributar, dentre outros impostos, o Imposto sobre Operações Relativas à Circulação de Mercadorias e sobre Serviços Prestações de Serviços de Transporte Interestadual, Intermunicipal de Comunicação - ICMS.

Alegando o livre uso de sua autonomia, os Estados, visando à atração de investimentos privados, geração de empregos e rendimentos locais, oferecem ao setor privado determinados benefícios fiscais, como reduções de base de cálculo e alíquotas, créditos especiais, isenções etc.

O problema é que, grande parte das vezes, esse incentivo tributário é concedido em desrespeito à forma prevista na Constituição Federal, e, quando há desrespeito à forma legalmente prevista, resta configurada uma competição fiscal responsável por um conflito entre os Estados da Federação brasileira, denominado "guerra fiscal".

Essa competitividade existe porque o imposto é atualmente uma das principais fontes de arrecadação de receita dos Estados e do Distrito Federal, e logo, 
•• Tributação, direitos fundamentais e desenvolvimento

produz efeitos diretos e cruciais na economia nacional. Apesar de a União implementar normas gerais de harmonização, buscando evitar grandes desigualdades entre os Estados no momento da arrecadação, as políticas atualmente empregadas não vêm gerando resultados eficazes na prática, pois, como dito, os Estados-membros na ânsia de aumentarem seu índice de desenvolvimento econômico, buscam alcançar maiores investimentos privados em seus territórios e, desta forma, acabam por conceder incentivos fiscais em total desrespeito com as citadas regras constitucionais de uniformização, principalmente, no que diz respeito aos convênios, que, obrigatoriamente, deveriam ser celebrados entre todos os entes.

Ademais, ainda que haja uma abrangente legislação sobre o tema, esta acaba por gerar inúmeras controvérsias doutrinárias. No âmbito judicial, o argumento utilizado por quem concede unilateralmente benefícios fiscais é sua utilização como instrumento de política de desenvolvimento regional e redução de desigualdades. Por sua vez, os Estados que se dizem prejudicados argumentam que essa prática constitui ofensa ao pacto federativo, já que haveria direta violação de regras específicas da Constituição Federal.

Desta forma, em meio a essa problemática, discute-se se a cobrança do tributo pelos Estados e pelo Distrito Federal é a melhor alternativa à política econômica do país, considerando o impacto nacional de sua instituição e arrecadação; questiona-se, ainda, se a cobrança seria otimizada se efetuada no Estado destino da mercadoria ou do serviço, pois, muitos defendem que cobrar o tributo na origem acaba por distorcer a real capacidade contributiva dos Estados, fomentando ainda mais as desigualdades regionais.

Assim, torna-se incontestável a importância da discussão da temática, que é objeto de discussões no Poder Legislativo, sobretudo, quando se trata da Reforma Tributária, no Poder Judiciário, que diariamente julga demandas questionando a legalidade dessas cobranças e isenções realizadas pelos Estados, e do Poder Executivo, responsável pela instituição da alíquota em cada Estado.

Admitir que a concessão ilegal de benefícios e a "guerra fiscal" ocorram, é menosprezar a essencialidade do imposto nos resultados econômicos do Brasil, nacional e internacionalmente. A tributação autônoma gera, corriqueiramente, conflito de interesses entre os Estados- membros, e como consequente, um clima de instabilidade tributária em meio a uma legislação legítima.

Há de se considerar a importância do planejamento tributário dos entes políticos no sentido do combate às fraudes, isenções ilegais de impostos e às práticas 
endêmicas que maculam o erário e sua destinação, pois, instituir normas de cobrança do ICMS ignorando o caráter cogente destas é conduta abusiva e ilegal, que, por isso mesmo, merece ser fortemente reprimida e sancionada.

Deste modo, é necessário que essa temática seja amplamente debatida, com o objetivo de se compreender mais profundamente a questão, possibilitando, assim, futuras reformas tributárias regulando a cobrança e a instituição do tributo de forma ainda mais eficiente e igualitária.

O presente estudo pretende tecer um aprofundamento em relação às consequências da determinação da competência estadual na instituição do ICMS, e destacará, nesse contexto, o problema da "guerra fiscal" entre esses entes federados.

\section{FEDERALISMO}

\subsection{O conceito e suas características}

Precedendo à análise da problemática em questão, cumpre-nos primeiramente observar alguns pontos e características relevantes sobre o conceito de "federalismo", primordial ao entendimento do presente estudo.

$\mathrm{Na}$ sistemática doutrinária atual, federalismo é o termo utilizado para denominar a teoria ideologicamente formulada para compreender a organização dos Estados sob a forma federativa ${ }^{1}$, bem como as semelhanças existentes entre os entes que deste modo se organizam. Diz respeito, sobretudo, à forma de divisão dos poderes políticos-constitucionais entre os diferentes níveis de governo.

\footnotetext{
Segundo o entendimento do professor Bernardo Gonçalves Fernandes: Estado Federal ou forma federativa é a forma de Estado em que há distribuição geográfica do poder político em função do território, na qual um ente é dotado de soberania e os outros entes de autonomia. Com isso, as características básicas do Federalismo podem ser assim definidas: a) indissolubilidade do pacto federativo; b) descentralização política entre as vontades central e regionais, na medida em que a federação pressupões a existência de, pelo menos duas ordens jurídicas, sendo uma central e uma parcial; c) Constituição rígida com um núcleo imodificável que não permita a secessão; d) existência de um órgão que represente e externalize a vontade do membros da federação de forma isonômica (paritária); e) autonomia financeira dos entes expressa na Constituição do ente soberano; f) a existência de um órgão de cúpula do Poder Judiciário que resolva os conflitos entre os entes de federação, impedindo assim a usurpação de competências e com isso o desrespeito a Constituição; g) auto-organização político-administrativa dos entes autônomos com a possibilidade de os mesmos produzirem suas próprias lei (auto normatização) terem seu próprio governo (autogoverno) e sua própria administração (autoadministração).
} 
•• Tributação, direitos fundamentais e desenvolvimento

Nesse sentido, é importante frisar que 'federação' e 'federalismo' são conceitos distintos, sendo o primeiro uma aplicação pontual do segundo. Uma vez divido em unidades autônomas politicamente governadas por um poder central, soberano, regido e limitado por uma Constituição, um Estado poderá ser considerado uma federação, logo, 'federação' relaciona-se à ideia de descentralização de poder. Já 'federalismo' é uma concepção puramente abstrata que busca definir pontos em comum entre as formas de organização dos Estados federais, a fim de traçar um modelo ideal que possa servir de parâmetro a qualquer Estado que se organize sob essa forma.

Assim, o aspecto primordial desse conceito de organização política- constitucional é a descentralização dos poderes e, consequentemente, do exercício desse poder que é conduzido por uma ordem jurídica única que deve ser respeitada. Essa dissociação do poder político - administrativo é o ponto crucial de estruturação do modelo federal e, com efeito, garante a repartição de competências entres os diferentes níveis de governo, que, ratificando, possuem autonomia organizacional, política, administrativa e financeira.

Nas palavras de Geraldo Ataliba², "ninguém pode fazer uma definição completa, miúda, de Federação, porque ela assume, em cada lugar, em cada época e em cada momento, feição diversa", no entanto, segundo o autor, "há traços essenciais que deverão estar presentes em todos os Estados, que se pretendam afirmar, federais". Desta forma, frisa-se que, a federação, ou melhor, a forma federativa de Estado é uma das características intrínsecas do modelo federalista, mas que com ele não se confunde.

Nas palavras de Brandão Junior", não há "um modelo ideal e abstrato que possa ser aplicado a toda gama de federações existentes", pois, cada ordem constitucional estabelece as especificidades de organização de sua federação a partir de soluçôes concretas e historicamente divergentes, entretanto, conforme preceitua Marcos Mendes ${ }^{4}$, é possível estabelecer comparações entre os Estados que adotam a forma federativa e, através dessas contraposições, não somente identificar características comuns, mas também, "estabelecer parâmetros de racionalidade e eficiência econômica que orientem os ajustes na organização das federaçôes”.

ATALIBA, Geraldo. Constituição e Constituinte: regime federativo. São Paulo: RT, 1987, p. 63. BRANDÃO JUNIOR, Salvador Cândido. Federalismo e ICMS: Estados-membros em "guerra fiscal”. São Paulo: USP - Faculdade de Direito, 2013, p. 28.

4 MENDES, Marcos. Federalismo fiscal. In: BIDERMAN, Ciro; ARVATE, Paulo. Economia do setor público no Brasil. Rio de Janeiro: Elsevier, 2004, p. 423. 
Diante do exposto e em linhas gerais, pode-se considerar que, amparando-se nos estudos doutrinários, as principais características do Federalismo, podem ser traçadas nas seguintes premissas: primeiramente, é necessária a existência de uma Constituição, ou lei "suprema", que institua a forma de Estado Federativo; devem existir pelo menos duas esferas de governo, dotadas de autonomia e, portanto, de Poder Legislativo, Executivo e Judiciário; é imprescindível que esses entes da federação sejam indissociáveis; e, por fim, deve haver uma repartição de competências legalmente definida.

Logo, a forma federativa consiste na efetividade prática constitucional da descentralização, isto é, na pluralidade governamental em uma única organização político-administrativa. Não obstante, exige a existência de um exercício harmônico e simultâneo, num mesmo território, de duas ou mais esferas de governos autônomas e por haver duas ou mais esferas de poder governamental sobre a sociedade, esta descentralização contribui para a divisão do poder e o afastamento do arbítrio.

Sendo assim, a divisão de competências define a autonomia dos entes políticos componentes da federação, uma vez que, autonomia é compreendida como sendo o exercício de governo próprio no âmbito destas competências traçadas pela Constituição Federal. Com estas duas características, José Afonso da Silva ${ }^{5}$ conceitua Estado Federal como forma de organização do Estado "politicamente e constitucionalmente descentralizado mediante uma Constituição rígida”, em que haverá pluralidade de ordens autônomas de governo num mesmo território e sobre a mesma população.

\subsection{O pacto federativo fiscal e a distribuição de competências}

Primeiramente é mister salientar os antecedentes históricos do federalismo brasileiro. A nossa primeira Constituição de 1824 definiu que a forma de Estado seria a do Estado unitário, altamente centralizado. Acontece que em novembro de 1889, o decreto n. 01 proclamou no Brasil uma República Federativa, com a devida transformação das Províncias em Estados Federados. Logo, a Constituição de 1891 foi a primeira a adotar a forma de Estado Federal, até então existente apenas via decreto.

SILVA, José Afonso. Federalismo e autonomias no Estado Brasileiro: federalismo nominal e federalismo de regiōes. In: I Simposium Internacional de Derecho Constitucional Autonómico. Espanha: Generalitat Valenciana, 1985, p. 39. 
-. Tributação, direitos fundamentais e desenvolvimento

Como explicado anteriormente, pode-se considerar que a adoção da forma federativa de Estado atua como um limitador de poder político, pois, como no caso do Brasil, ao conceder maior autonomia aos Estados e Municípios, a União, consequentemente, tem sua atuação demarcada e, com isso, sua própria esfera de poder e atuação limitada.

Porém, o poder político central surge como resultado da agregação dos poderes políticos locais, sendo que, ambas as estruturas só poderão coexistir com a integração política e jurídica resguardada pela Constituição Federal ${ }^{6}$.

Apesar de não haver uma hierarquização entre essas esferas atuantes, uma vez que cada um atua plenamente dentro de sua área de competência, vigora no modelo brasileiro de organização política uma preponderância do governo central sobre as demais esferas de governo subnacionais.

Visando explicar melhor essa divisão de poder entre os entes, a dogmática classifica o federalismo quanto ao seu grau de centralização como centrífugo e centrípeto e quanto ao critério de igualdade na distribuição das atribuições como sendo simétrico ou assimétrico. A organização brasileira é majoritariamente enquadrada como sendo centrífuga e simétrica.

Para estudiosos como Carlos Eduardo Dieder Reverbel ${ }^{7}$, que consideram que essa classificação está pautada na forma de concentração de poder, o federalismo brasileiro pode ser classificado como centrípeto, porque existe na organização constitucional do país um poder central forte, ao qual foram atribuídos mais "poderes, encargos e competências" do que para os outros entes descentrais. Diferentemente do centrífugo, no qual, para essa corrente, esses mesmos poderes, encargos e competências são distribuídos buscando a preservação da autonomia dos entes regionais e locais em face da União.

A maioria dos autores, contudo, utilizam as expressōes 'centrífuga' ou 'centrípeta' para representarem a forma como a federação foi concebida - se a federação foi constituída a partir da junção de Estados independentes, isto é, por agregação, diz-se que a formação se deu "em direção ao centro", ou seja, de forma centrípeta;

MIRANDA, Jorge. Teoria do Estado e da Constituição. 3. ed. Rio de Janeiro: Forense, 2011, p. 144.

REVERBEL, Carlos Eduardo Dieder. O federalismo numa visão tridimensional do direito. Porto Alegre: Livraria do Advogado, 2012, p. 18-19.

8 REVERBEL, Carolos Eduardo Dieder. Ibidem, p. 19. 
caso contrário, se a formação ocorre por desagregação, pela dissolução do ente central em entes menores, fala-se em federalismo centrífugo.

Deste modo, considera-se que a origem do federalismo brasileiro é centrífuga, visto que se trata um federalismo altamente centralizado, condensando competências à União.

Quanto à outra classificação consolidada, a primeira delas, simétrica, consiste no tratamento igualitário fornecido pela Constituição Federal, ao atribuir o mesmo grau de autoridade aos Estados-membros; enquanto na assimétrica, a Constituição Federal confere tratamento diferenciado aos entes descentralizados, institucionalizando os desníveis sociais mediante a busca de correção das desigualdades regionais existentes, com vistas a "conciliar a unidade na diversidade em homenagem ao princípio da igualdade" , sem que haja ofensa ao pacto federativo.

Portanto, citando novamente Augusto Zimmermann ${ }^{10}$, "a função da assimetria é precisamente observar os desníveis de existentes no interior do Estado, havendo-se de operar em face dos elementos da desigualdade interpartes, entre os agentes formadores do pacto federativo". Seguindo esse entendimento, Zimmermann afirma que os Estados no Brasil "são mantidos em igualdade jurídica pela arrogância centralista insensível à desigualdade de uns com outros, seja em densidade demográfica, dimensão territorial ou desenvolvimento econômico"11.

Nesse sentido, critica-se o federalismo simétrico existente no sistema brasileiro, pois, a federação brasileira, de forma equivocada insiste, desde de sua origem, em conferir um tratamento igualitário para seus Estados-membros.

No que se refere à repartição de competências ocorridas entre os níveis autônomos de poder, como instrumento para redução das assimetrias ocorridas em razão das distorções do federalismo assimétrico brasileiro, tem-se o federalismo cooperativo e o federalismo dual.

No federalismo dual, a separação de atribuições entre os entes federativos é extremamente rígida, não se vislumbrando cooperação ou interpenetração entre eles. Já no federalismo cooperativo as atribuições são exercidas de modo comum ou

\footnotetext{
REVERBEL, Carlos Eduardo Dieder. Ibidem, p. 18.

10 ZIMMERMANN, Augusto. Teoria geral do federalismo democrático. 2. ed. Rio de Janeiro: Lumen Juris, 2005, p. 61.

11 ZIMMERMANN, Augusto. Ibidem, p. 63.
} 
•• Tributação, direitos fundamentais e desenvolvimento

concorrente, havendo proximidade entre os entes federativos, que deverão atuar em conjunto $^{12}$.

Já o federalismo cooperativo, implantado no Brasil na Constituição Federal de 1934, objetivou o favorecimento da redução dos desequilíbrios regionais, da cooperação e da integração nacional ${ }^{13}$. Foi resultante de acordos intergovernamentais para aplicação de programas, realização de transferências voluntárias, financiamentos, subvençôes e auxilio conjunto, tendo como principal objetivo a livre cooperação entre os entes da Federação.

A Constituição de 1988 seguiu o entendimento das citadas constituições anteriores enumerando competências privativas, comuns e concorrentes. No entanto, José Maurício Conti ${ }^{14}$ esclarece que no Brasil o sistema federativo ainda possui resquícios de um federalismo dualista, "na medida em que estabelece campos específicos de atuação para cada uma das unidades, delimitando a área de atuação da União, dos Estados-membros e dos Municípios”, principalmente em relação à instituição de impostos. Desta forma, o professor conclui que o Brasil adota um sistema misto que incorpora técnicas das duas espécies de federalismo, uma vez que, como dito anteriormente, também estabelece campos de atuação concorrentes, desenvolvendo, assim, suas relações intergovernamentais.

Essas relações federativas de cooperação podem ser visualizadas nos artigos 23 e 24 da Constituição Federal de 1988, que elencam as competências comuns e concorrentes $^{15}$, entre a Uniāo, Estados, Distrito Federal e Municípios, de forma

12 LENZA, Pedro. Direito constitucional esquematizado. 18. ed. rev., atual. e ampl. São Paulo: Saraiva, 2014, p. 469-472.

13 BRANDÃO JUNIOR, Salvador Cândido. Federalismo e ICMS: Estados-membros em "guerra fiscal”. São Paulo: USP - Faculdade de Direito, 2013, p. 38.

14 CONTI, José Maurício. Federalismo fiscal e fundos de participação. São Paulo: Juarez de Oliveira, 2001, p. 24.

15 José Afonso da Silva, em razão da participação de uma ou mais entidade federativa na elaboração de normas ou realização de obras, classifica a repartição de competências em exclusiva, privativa, comum ou concorrente. Segundo José Afonso, competência exclusiva é aquela que "é atribuída a uma entidade com exclusão das demais", como as previstas no art. 21 da Constituição Federal. A denominada competência privativa é aquela "enumerada como própria de uma entidade, com possibilidade, no entanto, de delegação (art. 22 e seu parágrafo único) e de competência suplementar (art. 24 e seus parágrafos)". Aponta o autor que a diferença entre a competência exclusiva e a competência privativa é a possibilidade de delegação e suplementariedade das competências privativas. As competências comuns traduzem a faculdade de legislar ou praticar certos atos "consistindo na atuação comum às várias entidades, sem que o exercício de uma venha a excluir a competência da outra, que pode assim ser exercida cumulativamente (art. 23)”, 
que todos os entes da Federação devem colaborar para a execução das tarefas determinadas pela Carta Magna.

Ademais, o texto de 1988 em seus artigos 21 e 22 enumera competências da União, ressalvando no art. 22 a possibilidade de delegação; no artigo 25 prescreve os poderes reservados aos Estados e; residualmente, no artigo 30 elenca a competência no âmbito municipal.

A doutrina é pacífica ao apontar o princípio da predominância do interesse como sendo o critério geral utilizado para orientar a repartição de competências organizada no texto constitucional. Por meio desse critério, foram distribuídas à União matérias de predominante interesse geral (nacional), aos Estados tocaram assuntos de predominante interesse regional, ao ponto que aos Municípios atribuíram o tratamento de questões de interesse local.

De maneira geral, no que tange especificamente a distribuição de competências tributárias, a Carta de 1988, seguindo tal entendimento principiológico, manteve em poder da União os tributos sobre operações internacionais e os impostos incidentes sobre matérias mais voláteis, como a renda; aos Estados destinou as espécies incidentes sobre operações de circulação de bens e mercadorias e aos governos locais outorgou a tributação sobre os imóveis e serviços.

Destaca-se que, competência pode ser definida como a "faculdade juridicamente atribuída a uma entidade, ou a um órgão ou agente do poder público para emitir decisões nos limites da lei" ${ }^{\prime \prime}$. Entretanto, embora não seja um dever a ser desempenhado pelo ente ao qual se destina, o texto constitucional, ao enumerar competências exclusivas à União, acaba por evidenciar que não há completa igualdade de tratamento entre os entes federais.

De igual modo, pela leitura do texto constitucional aufere-se que, visando à obtenção pelos entes federados de meios financeiros para fazer frente aos seus

com atuação em pé de igualdade. Por fim, fala-se em competência concorrente quando existir o que se denomina de competência suplementar dos Estados, ao "formular normas que desdobrem o conteúdo de princípios ou normas gerais ou que supram a ausência ou omissão destas (art. 24, $\$ \$ 1$ a 4)", e enquanto não for editada a legislação federal, os Estados legislam com plenitude, ao passo que na edição da legislação federal, a legislação estadual anterior tem sua incidência afastada no trato do mesmo assunto e no que não lhe for compatível (SILVA, José Afonso. Curso de direito constitucional positivo. 25. ed. São Paulo: Malheiros, 2005, p. 481).

16 SILVA, José Afonso. Federalismo e autonomias no estado brasileiro: federalismo nominal e federalismo de regiōes. In: I Simposium Internacional de Derecho Constitucional Autonómico. Espanha: Generalitat Valenciana, 1985, p. 84. 
•• Tributação, direitos fundamentais e desenvolvimento

encargos, cumprir sua autonomia política e administrativa, e, desta maneira, satisfazer as eventuais necessidades coletivas, foram conferidas a estas unidades, de forma exclusiva, a instituição de impostos, bem como a competência para legislar sobre direito financeiro e estabelecer normas orçamentárias, em respeito às normas gerais expedidas pela União, sendo livre a aplicação desses recursos arrecadados.

José Afonso da Silva ensina que a repartição pela fonte de receita usualmente se dá em três planos: a) "competência exclusiva", compreendida nos impostos que nominalmente "caberão, exclusivamente a cada nível de governo", sendo que, no Brasil há competências exclusivas para instituir impostos distribuídas por campos de atuação para todos os entes federais; b) "competência comum" abrange tributos que, por sua natureza, são incindíveis em espécies economicamente diferenciadas, ligados como estão a uma atividade estatal diretamente imputável a um indivíduo (taxas e contribuiçôes) e, por fim; c) "competência residual", define que além das materialidades discriminadas para tributação por impostos, outras poderão ser remanescentes, tanto em regime de exclusividade pelo ente federativo assim nomeado, quanto em regime de livre concorrência por quaisquer um deles. No Brasil, a competência residual é atribuída à União no artigo 154 , I, da Constituição Federal ${ }^{17}$.

Há, assim, uma repartição vertical ${ }^{18}$ de competências entre os entes federados, pois, ainda que sobre um mesmo tema, possa haver a atuação de diferentes níveis de governo, compete à União o estabelecimento de "normas gerais", enquanto que para a legislação regional e local caberá o papel de apenas suplementar essa eventual lei já editada.

Neste ponto, analisa-se então a competência tributária, concedida na Constituição Federal aos entes, com o escopo de fornecer-lhes autonomia financeira. A expressão "competência tributária" assume diferentes concepçôes - pode ser entendida como a aptidão do Poder Executivo em expedir decretos, portarias e instruções normativas acerca de um determinado tributo e até mesmo como a ação do particular ao construir a norma individual e concreta resultante no recolhimento do tributo ${ }^{19}$.

Classificação dada por José Afonso da Silva. In: SILVA, José Afonso. Curso de direito constitucional positivo. 25. ed. São Paulo. Malheiros, 2005, p. 721.

18 Técnica proveniente do modelo de federalismo cooperativo, na qual dois ou mais entes atuam conjuntamente para uma mesma matéria.

19 CARVALHO, Paulo de Barros. Curso de direito tributário. 19. ed. São Paulo: Saraiva, 2007, p. 236. 
Para o momento, a acepção de competência tributária que cabe aqui se refere à possibilidade de criação de leis para instituição de tributos, isto é, à capacidade conferida constitucionalmente ao Poder Legislativo para inovar o sistema positivo com regras tributárias.

Entretanto, nosso modelo federativo tem reconhecido que, não raro, a distribuição das competências tributárias não é suficiente para proporcionar aos diversos níveis de governo os recursos necessários à consecução de suas atribuições, falando-se, então, em um federalismo de cooperação, fruto do Estado Social, que, como já dito anteriormente, caracteriza-se, fundamentalmente, pela mútua assistência entre os entes federados.

Essa cooperação tributária e financeira manifesta-se, sobretudo, nas transferências intergovernamentais que podem se concretizar mediante transferências voluntárias e/ou mediante a repartição de receitas tributárias.

A primeira modalidade depende de vinculação prévia entre os entes e sua estipulação dá-se por meio do arbítrio do ente concedente, concretizando-se através de convênios ou instrumentos similares. A segunda ocorre através da estipulação de um percentual do produto arrecadado com a tributação e provém diretamente do texto constitucional ${ }^{20}$, podendo, excepcionalmente, ser estabelecida mediante lei complementar.

Sendo assim, no âmbito fiscal é assegurado aos poderes central, regionais e locais fontes de receitas para que possam ter efetiva autonomia política, administrativa e financeira, pois, ainda que um Estado desenvolva atividades econômicas, ao explorar o seu próprio patrimônio, certamente, sua principal fonte de receitas será o tributo ${ }^{21}$.

Assim, nota-se que a estruturação de um federalismo fiscal está intimamente relacionada à correspondente distribuição da competência tributária, logo, à escolha da base da tributação (consumo, renda ou patrimônio), bem como à existência de outros mecanismos que garantam uma distribuição otimizada dos recursos oriundos da arrecadação dos tributos. Frisa-se que, o constituinte de 1988, ao consagrar o modelo federativo no âmbito da arrecadação das receitas, instituiu um

20 Vide artigos 157 a 159 da Constituição Federal de 1988.

21 ARRECADAÇÃO UF 2017, In: Receita Federal, Ministério da Fazenda. Disponível em: <http://idg.receita.fazenda.gov.br/dados/receitadata/arrecadacao/arrecadacao-por-estado/arrecadacao-uf-2017> Acesso em: 20 out. 2017. 
•• Tributação, direitos fundamentais e desenvolvimento

complexo sistema de distribuição de competências e recolocação de receitas de modo a proporcionar aos entes nacional e subnacionais recursos suficientes à satisfação de suas finalidades institucionais.

O Brasil, devido a sua grande extensão territorial e heterogeneidade de suas regiões apresenta em cada governo regional um diferente nível de capacidade fiscal e administrativa, assim como diferentes perfis de demandas por bens públicos, motivo pelo qual um sistema federativo é o que melhor se ajusta à sua realidade, dado que permite à administração pública adaptar-se às necessidades e idiossincrasias locais, maximizando a eficiência do setor público no que tange ao aspecto financeiro.

\subsection{Autonomia dos entes federados}

Conclui-se a partir do tópico anterior, que a distribuição de competências é pressuposto para o exercício da autonomia, pois, será ela a conduzir o conteúdo da atividade autônoma dos entes. Nesse sentido, José Afonso da Silva ${ }^{22}$ disserta que a autonomia dos Estados membros se fundamenta na existência de "governo próprio e posse de competência exclusiva”.

Considerando todo o explanado, de maneira simplificada, define-se autonomia como sendo a capacidade de desenvolver atividades dentro de limites previamente circunscritos pelo ente soberano. Logo, é um poder limitado e condicionado por um poder superior e supremo que na prática, se subdivide em uma tríplice capacidade: auto-organização [ou normatização própria], autogoverno e autoadministração.

Conforme explica Salvador Candido Brandão Junior ${ }^{23}$, a autonomia dos Estados-membros "corresponde ao exercício pelos entes políticos de seu campo de atribuições constitucionais por órgãos próprios, sem a intervenção do governo central", sendo, essa repartição constitucional de competências quesito crucial ao convívio político dos entes componentes da federação por garantir suas atribuições e áreas de atuação.

SILVA, José Afonso. Federalismo e autonomias no estado brasileiro: federalismo nominal e federalismo de regióes. In: I Simposium Internacional de Derecho Constitucional Autonómico. Espanha: Generalitat Valenciana, 1985, p. 484.

23 BRANDÃO JUNIOR, Salvador Cândido. Federalismo e ICMS: Estados-membros em "guerra fiscal”. São Paulo: USP - Faculdade de Direito, 2013, p. 50. 
Segundo o autor, a autonomia é então, conceito jurídico, e "pressupõe um poder de direito público não soberano, que pode, em virtude de direito próprio e não em virtude de delegação, estabelecer regras de direito obrigatórias" ${ }^{24}$. Logo, pode ser compreendida como um governo privativo exercido de acordo com os limites de atribuiçõos traçados pela Constituição Federal.

O artigo 18 da Constituição Federal estabelece que: "A organização político-administrativa da República Federativa do Brasil compreende a União, os Estados, o Distrito Federal e os Municípios, todos autônomos, nos termos desta Constituição".

O dispositivo mencionado ao estabelecer que são todos os entes "autônomos, nos termos desta Constituição", evidencia que essa liberdade conferida à União, aos Estados membros, ao Distrito Federal e aos Municípios é condicionada às normas constitucionais, sobretudo, às normas que disciplinam a repartição de competências. Portanto, esse regime autônomo não é incondicional e ilimitado, estando sujeito à fiscalização administrativa e judicial com vistas a manter o equilíbrio federal.

É o que dispõe o artigo 25 da Carta Magna: "Os Estados organizam-se e regem-se pelas Constituições e leis que adotarem, observados os princípios desta Constituição (...) $\$ 1^{\circ}$ São reservadas aos Estados as competências que não lhes sejam vedadas por esta Constituição".

No entanto, é válido observar que, respeitados os limites constitucionais, assim entendidos como os princípios constitucionais e as repartiçôes de competências, tanto a Constituição Estadual, quanto sua legislação estadual será elaborada, deliberada e aprovada por órgãos próprios do Estado, sem a condição de aprovação ou interferência da União.

Assim, não há intervenção ou controle prévio do governo central no exercício da autonomia dos Estados-membros, havendo apenas um controle repressivo, jurisdicional, para verificação da compatibilidade da Constituição Estadual e da legislação estadual perante a Constituição Federal, tarefa esta a ser desempenhada pelo Supremo Tribunal Federal25.

As normas constitucionais que concedem liberdade de atuação administrativa e legislativa sem intervenção ou controle prévio do governo central representam, ao

24 BRANDÃO JUNIOR, Salvador Cândido. Ibidem, p. 42.

25 CARRAZZA, Roque António. Curso de direito constitucional tributário. 27. ed. São Paulo: Saraiva, 2011, p. 139-155. 
•• Tributação, direitos fundamentais e desenvolvimento

mesmo tempo, uma concessão e uma vedação ${ }^{26}$, porque, ainda que os órgãos estaduais elaborem, deliberem e aprovem, essa atividade não está isenta de uma eventual intervenção ou controle repressivo jurisdicional para a verificação de sua compatibilidade com o que preceitua a norma federal.

Ademais, a autonomia das entidades federadas exprime uma autonomia administrativa e política que, para serem garantidas tornam imprescindível que estes entes também estejam dotados de autonomia financeira. José Maurício Conti ${ }^{27}$ considera ser a autonomia financeira de "fundamental importância, não se concebendo ente autônomo que não disponha de recursos bastantes para suas necessidades". Conti argumenta que essa espécie de autonomia, para existir, exige dois requisitos: i) uma forma independente das demais unidades federadas para obter recursos financeiros, através de um sistema de repartição de fontes de receitas; ii) recursos suficientes para cobrir todas as despesas de seus encargos ${ }^{28}$.

Portanto, em uma federação, para que possa ser assegurada autonomia financeira suficiente à relativa independência dos entes regionais ao poder central, é fundamental que os Estados detenham poder para instituir e arrecadar tributos com exclusividade.

Complementando todo o exposto, oportuno citar a compreensão do professor Luís Eduardo Schoueri ${ }^{29}$, que, ao defender que seja assegurada, às pessoas jurídicas de direito público, autonomia financeira, ressalta a diferença entre a discriminação de renda e a discriminação de competências. Para Schoueri, a autonomia implica em discriminação de renda, pois, a discriminação de competências, apesar de ser instrumento para obtenção de recursos, por si só é incapaz de garantir uma fonte de receita.

\section{2. $\mathrm{O}$ ICMS}

Com a Constituição de 1934 surgiu o IVC - Imposto sobre Vendas e Consignações, que, de natureza mercantil, possuía como fato gerador cada venda distinta realizada. O imposto incidia sobre cada uma das fases da circulação da

26 CARRAZZA, Roque António. Ibidem, p. 488.

27 Cf. CONTI, José Maurício. Federalismo fiscal e reforma tributária: utopia ou realidade? In: SCHOUERI, Luís Eduardo (Coord.). Direito tributário. Homenagem a Paulo de Barros Carvalho. São Paulo: Quartier Latin, 2008, p. 908.

28 CONTI, José Maurício. Ibidem, p. 908.

29 SCHOUERI, Luís Eduardo. Direito tributário. São Paulo: Saraiva, 2011, p. 238. 
mercadoria - do produtor até o consumidor final - sendo que, em cada uma dessas fases era exigido, repetidamente, sobre a base de cálculo integral. Isto é, em cada operação de uma cadeia plurifásica, a base de cálculo era elevada pela adição de novas margens de lucro, de novas despesas acessórias, e até pelo acréscimo do próprio imposto que recaiu sobre as operaçóes anteriores.

Os Estados membros se utilizavam da cumulatividade do imposto para criar normas de tributação discriminatória e, acabavam por originar entraves às atividades interestaduais e intermunicipais. Evidente que, a própria estrutura do imposto elevava consideravelmente o preço final das mercadorias e permitia a diferenciação de alíquotas nas operações interestaduais, consolidando uma concorrência fiscal entre as unidades federadas que em nada estimulava a transferência de renda dos Estados mais ricos aos mais pobres.

Com o objetivo de corrigir essa situação, de forma a evitar conflitos de disposições divergentes de um Estado para outro, bem como visando uniformizar a legislação tributária em todo território nacional, na Constituição de 1946 foi introduzido o art. 5, XV, "b”, conferindo à União competência para estabelecer normas gerais sobre direito financeiro.

Posteriormente, já em meados dos anos 50, no contexto de elaboração do Código Tributário Nacional (Lei 5.172 de 1966), ressaltou-se a necessidade de uma codificação que visasse, sobretudo, a unificação do direito tributário federal, estadual e municipal, tendo em vista que num mesmo local do território pátrio o contribuinte é disputado pelas três competências fiscais.

Assim, nessa conjuntura de implantação de medidas positivas em busca da reciprocidade de reconhecimento do imposto cobrado por outro Estado, a Comissão de Reforma propôs a ampliação da competência das Resoluções do Senado Federal e a inclusão da figura das Leis Complementares no texto constitucional.

As resoluções do Senado Federal, que já estavam disciplinadas desde a Constituição de 1946, com a reforma, tiveram seu campo de atuação expandido com vistas a assegurar o caráter uno do sistema tributário nacional.

As regras, entretanto, para estabelecer as alíquotas internas mínimas e máximas possuem algumas diferenças. Para ambos os casos deverá ser utilizado como instrumento normativo a Resolução do Senado Federal, todavia o quorum para apresentação de proposta de Resolução e sua aprovação se diferem: para a fixação da alíquota mínima, deve ser apresentada proposta por $1 / 3$ de seus membros 
-• Tributação, direitos fundamentais e desenvolvimento

(27 senadores) e aprovada por maioria absoluta (41 senadores), enquanto que para a fixação da alíquota máxima, deve ser apresentada proposta pela maioria absoluta dos membros (41 senadores) e aprovada por dois terços dos seus membros (54 senadores). Ou seja, para se fixar a alíquota máxima é necessário um quorum maior.

Quanto às leis complementares, como não eram previstas expressamente na Constituição Federal de 1946, foram incluídas no texto da Constituição Federal de 1967, como de competência do Congresso Nacional, sendo que a iniciativa das leis, também foi atribuída às Assembleias Legislativas dos Estados, no quorum de mais da metade dos Estados e cada qual pela maioria de seus membros.

Não obstante as alterações supramencionadas, a reforma tributária também se materializou na Emenda Constitucional n. 18/65 que instaurou o ICM - Imposto sobre Circulação de Mercadorias, em substituição ao IVC.

Tal tributo inovava no sentido de não apresentar as características de cumulatividade, próprias do imposto que lhe antecedeu - seu pagamento era feito a partir do cálculo da diferença entre o valor da operação tributada e o da operação anterior, ou seja, era realizado sobre o valor agregado à mercadoria.

Vale frisar, que o ICM foi instituído em um contexto no qual se buscava a integração do sistema tributário, tendo em vista o ambiente competitivo instaurado pelos Estados produtores e consumidores de mercadorias quando vigente o Imposto sobre Venda e Consignações (IVC).

Ademais, pertinente pontuar que na Constituição de 1967, bem como na sua Emenda n. 01/69, foram mantidas todas as alterações promovidas pela Emenda n. 18/65, apenas incluindo no campo impositivo as operações de circulação de lubrificantes e combustíveis líquidos.

Nesse diapasão, na tentativa de discriminar à União apenas impostos com efeitos econômicos em âmbito nacional, a Constituição Federal de 1988 instituiu o ICMS, mediante a expansão do campo de incidência do ICM, de forma que o novo tributo passou a alcançar todas as modalidades de circulação de mercadorias e não somente aquelas realizadas sob a forma de negócio jurídico de venda.

Posteriormente, a Emenda Constitucional n. 03/93, devido à retirada dos impostos sobre serviços de transportes e de comunicação da esfera de competência tributária da União, conferiu nova redação ao art. 155, I, b, da CF/88, incluindo, ainda, ao campo de incidência do ICMS as prestações destes serviços.

Destaca-se que, foi mantido o regime de não cumulatividade e a competência do Senado Federal para, mediante Resolução, e do Congresso Nacional, mediante 
Lei Complementar, fixarem os limites de alíquota, bem como seus pressupostos de incidência, base de cálculo, contribuintes, isençōes etc., fazendo cessar, em tese, as desigualdades tributárias entre Estados produtores e consumidores.

Atualmente, é na Lei Complementar 87/1996, denominada Lei Kandir, onde estão disciplinadas as principais disposições sobre o ICMS - Imposto Sobre Operações Relativas à Circulação de Mercadorias e Sobre Prestações de Serviços de Transporte Interestadual, Intermunicipal e de Comunicação, tributo de competência estadual, de regime não cumulativo, cuja legislação específica varia de Estado para Estado.

\subsection{O ICMS na Constituição Federal de $\mathbf{1 9 8 8}$}

A Constituição Federal, no artigo 155 concede aos Estados a competência para a instituição do ICMS e estabelece algumas limitações e exclusões, conforme será demonstrado pela própria redação do supramencionado a seguir exposto.

Em relação ao ICMS, assim prescreve o artigo 155, in verbis:

Art. 155. Compete aos Estados e ao Distrito Federal instituir impostos sobre:

(...)

II - operações relativas à circulação de mercadorias e sobre prestaçôes de serviços de transporte interestadual e intermunicipal e de comunicação, ainda que as operaçôes e as prestaçōes se iniciem no exterior;

(...)

$\$ 2^{\circ} \mathrm{O}$ imposto previsto no inciso II atenderá ao seguinte:

I - será não cumulativo, compensando-se o que for devido em cada operação relativa à circulação de mercadorias ou prestação de serviços com o montante cobrado nas anteriores pelo mesmo ou outro Estado ou pelo Distrito Federal;

II - a isenção ou não incidência, salvo determinação em contrário da legislação:

a) não implicará crédito para compensação com o montante devido nas operaçôes ou prestações seguintes;

b) acarretará a anulação do crédito relativo às operações anteriores;

III - poderá ser seletivo, em função da essencialidade das mercadorias e dos serviços;

IV - resolução do Senado Federal, de iniciativa do Presidente da República ou de um terço dos Senadores, aprovada pela maioria absoluta de seus membros, estabelecerá as alíquotas aplicáveis às operaçôes e prestações, interestaduais e de exportação;

$\mathrm{V}$ - é facultado ao Senado Federal:

a) estabelecer alíquotas mínimas nas operações internas, mediante resolução de iniciativa de um terço e aprovada pela maioria absoluta de seus membros; 
b) fixar alíquotas máximas nas mesmas operações para resolver conflito específico que envolva interesse de Estados, mediante resolução de iniciativa da maioria absoluta e aprovada por dois terços de seus membros;

VI - salvo deliberação em contrário dos Estados e do Distrito Federal, nos termos do disposto no inciso XII, $g$, as alíquotas internas, nas operações relativas à circulação de mercadorias e nas prestações de serviços, não poderão ser inferiores às previstas para as operações interestaduais;

VII - nas operações e prestações que destinem bens e serviços a consumidor final, contribuinte ou não do imposto, localizado em outro Estado, adotar-se-á a alíquota interestadual e caberá ao Estado de localização do destinatário o imposto correspondente à diferença entre a alíquota interna do Estado destinatário e a alíquota interestadual;

VIII - a responsabilidade pelo recolhimento do imposto correspondente à diferença entre a alíquota interna e a interestadual de que trata o inciso VII será atribuída:

a) ao destinatário, quando este for contribuinte do imposto;

b) ao remetente, quando o destinatário não for contribuinte do imposto;

IX - incidirá também:

a) sobre a entrada de bem ou mercadoria importados do exterior por pessoa física ou jurídica, ainda que não seja contribuinte habitual do imposto, qualquer que seja a sua finalidade, assim como sobre o serviço prestado no exterior, cabendo o imposto ao Estado onde estiver situado o domicílio ou o estabelecimento do destinatário da mercadoria, bem ou serviço;

b) sobre o valor total da operação, quando mercadorias forem fornecidas com serviços não compreendidos na competência tributária dos Municípios;

$\mathrm{X}$ - não incidirá:

a) sobre operações que destinem mercadorias para o exterior, nem sobre serviços prestados a destinatários no exterior, assegurada a manutenção e o aproveitamento do montante do imposto cobrado nas operações e prestaçóes anteriores;

b) sobre operações que destinem a outros Estados petróleo, inclusive lubrificantes, combustíveis líquidos e gasosos dele derivados, e energia elétrica;

c) sobre o ouro, nas hipóteses definidas no art. $153, \$ 5^{\circ}$;

d) nas prestações de serviço de comunicação nas modalidades de radiodifusão sonora e de sons e imagens de recepção livre e gratuita;

XI - não compreenderá, em sua base de cálculo, o montante do imposto sobre produtos industrializados, quando a operação, realizada entre contribuintes e relativa a produto destinado à industrialização ou à comercialização, configure fato gerador dos dois impostos;

XII - cabe à lei complementar:

a) definir seus contribuintes;

b) dispor sobre substituição tributária;

c) disciplinar o regime de compensação do imposto; 
d) fixar, para efeito de sua cobrança e definição do estabelecimento responsável, o local das operações relativas à circulação de mercadorias e das prestações de serviços; e) excluir da incidência do imposto, nas exportaçōes para o exterior, serviços e outros produtos além dos mencionados no inciso X, $a$;

f) prever casos de manutenção de crédito, relativamente à remessa para outro Estado e exportação para o exterior, de serviços e de mercadorias;

g) regular a forma como, mediante deliberação dos Estados e do Distrito Federal, isençôes, incentivos e benefícios fiscais serão concedidos e revogados.

h) definir os combustíveis e lubrificantes sobre os quais o imposto incidirá uma única vez, qualquer que seja a sua finalidade, hipótese em que não se aplicará o disposto no inciso $\mathrm{X}, b$;

i) fixar a base de cálculo, de modo que o montante do imposto a integre, também na importação do exterior de bem, mercadoria ou serviço.

$\$ 3^{\circ}$ À exceção dos impostos de que tratam o inciso II do caput deste artigo e o art. 153, I e II, nenhum outro imposto poderá incidir sobre operações relativas a energia elétrica, serviços de telecomunicações, derivados de petróleo, combustíveis e minerais do País.

$\$ 4^{\circ} \mathrm{Na}$ hipótese do inciso XII, $h$, observar-se-á o seguinte:

I - nas operaçôes com os lubrificantes e combustíveis derivados de petróleo, o imposto caberá ao Estado onde ocorrer o consumo;

II - nas operações interestaduais, entre contribuintes, com gás natural e seus derivados, e lubrificantes e combustíveis não incluídos no inciso I deste parágrafo, o imposto será repartido entre os Estados de origem e de destino, mantendo-se a mesma proporcionalidade que ocorre nas operações com as demais mercadorias;

III - nas operaçôes interestaduais com gás natural e seus derivados, e lubrificantes e combustíveis não incluídos no inciso I deste parágrafo, destinadas a não contribuinte, o imposto caberá ao Estado de origem;

IV - as alíquotas do imposto serão definidas mediante deliberação dos Estados e Distrito Federal, nos termos do $\$ 2^{\circ}$, XII, $g$, observando-se o seguinte:

a) serão uniformes em todo o território nacional, podendo ser diferenciadas por produto;

b) poderão ser específicas, por unidade de medida adotada, ou ad valorem, incidindo sobre o valor da operação ou sobre o preço que o produto ou seu similar alcançaria em uma venda em condiçốes de livre concorrência;

c) poderão ser reduzidas e restabelecidas, não se lhes aplicando o disposto no art. 150, III, $b$;

$\$ 5^{\circ}$ As regras necessárias à aplicação do disposto no $₫ 4^{\circ}$, inclusive as relativas à apuração e à destinação do imposto, serão estabelecidas mediante deliberação dos Estados e do Distrito Federal, nos termos do $\$ 2^{\circ}$, XII, g. (...)

Diante do exposto, cabe destacar, no dispositivo legal em epígrafe, alguns pontos explícitos no $\$ 2^{\circ}$, relevantes ao estudo do presente trabalho: 
-. Tributação, direitos fundamentais e desenvolvimento

Primeiramente, através de simples leitura do artigo percebe-se que uma das características principais do ICMS é sua não cumulatividade. Expressa no inciso I representa um sistema de débito e crédito, no qual é abatido do montante devido pelo contribuinte o valor pago por este nas etapas anteriores de incidência. Tal mecanismo repercute em toda ordem tributária nacional, assunto que será tratado de forma circunstanciada em tópico seguinte.

$\mathrm{O}$ inciso II prescreve exceções ao princípio elencado no inciso anterior. Em sua alínea "a" faz referência ao que se denomina "efeito de recuperação", que, melhor explicado no capítulo seguinte, consiste basicamente na recuperação do imposto nas etapas seguintes de uma cadeia produtiva, quando houver uma isenção ou uma redução de alíquota, pois, considera-se que na hipótese de isenção não haverá crédito a compensar e que, na hipótese de redução de alíquota, haverá um crédito inferior ao débito.

A alínea "b", por sua vez, ao ordenar a anulação do crédito das operações anteriores, representa o que se denomina de regra de reversão, consistente no estorno do crédito do contribuinte em suas aquisições de mercadorias ${ }^{30}$.

Os incisos IV e V tratam da atribuição do Senado Federal para estabelecer as alíquotas, sendo, nos incisos posteriores, definidas as regras de definição e aplicação dessas alíquotas em situações específicas.

Conforme preceitua o inciso VI, pode ser estabelecida pelo Senado Federal uma alíquota piso nas operações internas, que corresponderá à interestadual. Até o limite deste piso, o legislador estadual é livre para reduzir alíquotas nas operações internas, porém, abaixo desse piso é necessária a deliberação entre os Estados autorizando que a redução de alíquota ultrapasse esse limite, papel que, em regra, deverá ser desempenhado pelo CONFAZ. Neste ponto reside uma das principais causas que envolvem o problema da 'Guerra Fiscal', tema que será melhor desenvolvido posteriormente.

Os incisos VII e VIII, alterados pela Emenda Constitucional 87 de 2015, veiculam comandos imperativos, prevendo a distribuição das receitas por meio do diferencial de alíquota interestadual e evidenciam em seus comandos que a Constituição Federal adotou um misto de princípio da origem e do destino, repartindo entre os Estados a arrecadação do ICMS - será devido no destino na hipótese em que o destinatário não seja consumidor final da mercadoria, a contrario sensu,

BRANDÃO JUNIOR, Salvador Cândido. Federalismo e ICMS: Estados-membros em "guerra fiscal”. São Paulo: USP - Faculdade de Direito, 2013. 
caso o destinatário seja consumidor final da mercadoria ou do serviço, o imposto será devido integralmente no Estado de origem, ou seja, pelo Estado produtor, industrial, comerciante ou prestador de serviço.

O inciso IX, alínea "a" determina a incidência do imposto na importação, determinando que deverá ser pago por pessoa física ou jurídica, qualquer que seja a sua finalidade, assim como sobre o serviço prestado no exterior, cabendo o imposto ao Estado onde estiver situado o domicílio ou estabelecimento do destinatário da mercadoria, bem ou serviço.

O inciso X prevê situações em que não haverá incidência. Sua alínea "a”, alterada pela Emenda Constitucional n. 42/2003, normatiza a não incidência do imposto em operaçôes ou prestaçóes que destinem mercadorias para o exterior, assegurando a manutenção do crédito e o aproveitamento do montante do imposto cobrado nas fases anteriores, para afastar a regra da reversão. Contudo, oportuno pontuar que, essa desoneração de exportações é, hoje, motivo de controvérsia.

Autores como Alcides Jorge Costa ${ }^{31}$ afirmam que no Brasil os Estados sempre opuseram resistência à ideia da desoneração dos produtos exportados, mas que, de modo geral, os países fazem as importaçōes ficarem sujeitas ao imposto e as exportações, isentas. De igual modo, Salvador Cândido Junior ${ }^{32}$, defende que "não se trata de uma política econômica e tributária da União Federal, mas sim da Nação, que se pretende ver inserida num contexto de comércio internacional".

O inciso XII assegura que a atual Constituição manteve como atribuição do Congresso Nacional a prerrogativa de estabelecer as normas de arrecadação e a base de incidência dos impostos estaduais, como contrapartida necessária da homogeneidade dessas regras no território nacional, pois, o inciso em questão prescreve as matérias reservadas à regulamentação por Lei Complementar, que, nas palavras de Ives Gandra da Silva Martinss33, "é uma lei nacional, uma lei da Federação, produzida pelo aparelho legislativo da União e emprestada a todas as unidades federativas".

Portanto, tendo em vista a integração do sistema tributário nacional no contexto na unidade nacional, bem como a necessidade de conferir uniformidade à

31 COSTA, Alcides Jorge. ICM na Constituição e na lei complementar. São Paulo: Resenha Tributária, 1978, p. 67.

32 BRANDÃO JUNIOR, Salvador Cãndido. Federalismo e ICMS: Estados-membros em "guerra fiscal". São Paulo: USP - Faculdade de Direito, 2013, p. 83.

33 MARTINS, Ives Gandra da Silva. Estímulos fiscais no ICMS e a unanimidade constitucional. In: Concessão de Benefícios Fiscais no âmbito do ICMS. São Paulo: Noeses, 2012, p. 10. 
•• Tributação, direitos fundamentais e desenvolvimento

disciplina jurídica do ICMS, conclui-se que o comando da uniformização vem 'de cima para baixo', de tal forma que as regras matrizes de incidência expedidas pelos Estados e Distrito Federal deverão manter consonância em seu conteúdo.

\subsection{Características gerais do imposto}

De forma a evitar excurso, não compreende como objeto deste trabalho um aprofundamento acerca dos elementos de incidência do imposto, como os aspectos quantitativos, temporais e materiais. Esforça-se, por outro lado, em verificar seu caráter nacional e suas regras de aplicação em todo território nacional, visto que, o legislador estadual deve se ater às limitaçôes formais e materiais dispostas na Constituição Federal para tratar do ICMS.

Corroborando seu grau de importância aos interesses nacionais, além dos princípios constitucionais do sistema tributário, o tributo em estudo é regido por mais dois princípios específicos, o da não cumulatividade e o da seletividade.

Dizer que o imposto é não cumulativo, conforme previsto no artigo $155, \$ 2^{\circ}$, incisos I e II da Constituição Federal, significa dizer que em sua cobrança é compensado "o que for devido em cada operação relativa à circulação de mercadorias ou prestação de serviços com o montante cobrado nas anteriores pelo mesmo ou por outro Estado ou pelo Distrito Federal"; isto é, a pessoa física ou jurídica somente recolhe a parcela que agregar ao produto.

Sendo assim, ao sujeito passivo da obrigação é assegurado o direito de creditar-se do imposto que já foi cobrado em operações resultantes da entrada real ou simbólica de mercadorias no estabelecimento; inclusive, as destinadas ao consumo próprio do devedor. Logo, o princípio da não cumulatividade é mandamento que busca garantir a neutralidade do ICMS nas diversas fases da cadeia produtiva, independentemente do número de operações.

No que concerne ao princípio da seletividade, diz-se que o ICMS é também um imposto seletivo, porque é cobrado em função da essencialidade das mercadorias e serviços. Expresso no art. $155 \$ 2^{\circ}$, III, da Carta Magna, este princípio determina que as alíquotas deverão ser proporcionais à essencialidade da mercadoria e/ ou do serviço de forma a atingir com menor ônus as mercadorias e serviços essenciais à garantia da dignidade humana ${ }^{34}$.

Dependendo do Estado, bebidas, fumos, iates, energia elétrica e comunicações são oneradas pelo ICMS com alíquota superior à aplicável às demais mercadorias e serviços. O Estado de 
Conforme expressa disposição do artigo $2^{\circ}$ da Lei Complementar n. 87/96, o imposto incide sobre:

I - operações relativas à circulação de mercadorias, inclusive o fornecimento de alimentação e bebidas em bares, restaurantes e estabelecimentos similares;

II - prestaçôes de serviços de transporte interestadual e intermunicipal, por qualquer via, de pessoas, bens, mercadorias ou valores;

III - prestaçôes onerosas de serviços de comunicação, por qualquer meio, inclusive a geração, a emissão, a recepção, a transmissão, a retransmissão, a repetição e a ampliação de comunicação de qualquer natureza;

IV - fornecimento de mercadorias com prestação de serviços não compreendidos na competência tributária dos Municípios;

$\mathrm{V}$ - fornecimento de mercadorias com prestação de serviços sujeitos ao imposto sobre serviços, de competência dos Municípios, quando a lei complementar aplicável expressamente o sujeitar à incidência do imposto estadual.

Sintetizando o acima exposto, o tributo em questão é gerado a partir da circulação de mercadorias e serviços de transporte e telecomunicação, sendo, o momento de ocorrência do fator gerador o instante da saída da mercadoria de um determinado local. Ou seja, é indispensável que haja a circulação, a movimentação da mercadoria para que o imposto possa ser cobrado ${ }^{35}$.

Quanto ao sujeito passivo da operação, conforme preceitua o artigo $4^{\circ}$ da Lei Complementar n. 87, é contribuinte do ICMS:

(...) qualquer pessoa, física ou jurídica, que realize, com habitualidade ou em volume que caracterize intuito comercial, operaçóes de circulação de mercadoria ou prestações de serviços de transporte interestadual e intermunicipal e de comunicação, ainda que as operaçōes e as prestaçōes se iniciem no exterior.

Incluídos nesse rol também estão pessoas físicas ou jurídicas que, mesmo sem habitualidade importe mercadorias do exterior, independentemente de destiná-las a consumo ou ao ativo permanente do estabelecimento, e a pessoa destinatária de serviço prestado no exterior ou de serviço cuja prestação se tenha iniciado no exterior.

No que se refere à questão da competência para a cobrança e arrecadação do imposto, reitera-se que o ICMS é tributo de competência estadual, sendo, seu

São Paulo, por exemplo, onera o consumo de energia elétrica com alíquotas variáveis de acordo com o tipo de consumidor (residencial, agricultor etc. - seletivamente), e também de acordo com a quantidade de energia elétrica consumida.

35 O artigo 12 da Lei Complementar n. 87 dispóe com precisão o aspecto temporal de ocorrência do ICMS. 
•• Tributação, direitos fundamentais e desenvolvimento

aspecto espacial coincidente com o limite geográfico do Estado sobre o qual ocorreu seu fato gerador. Percebe-se que definir o local da operação e, consequentemente, do fato gerador do imposto, é fundamental para que se possa determinar qual ente poderá exigir o tributo.

Em linhas gerais, o local do estabelecimento de onde saí uma mercadoria determina a competência. Nesse caso o tributo é devido ao Estado cujo estabelecimento está sediado no momento do fato gerador do imposto, ou seja, no momento da saída da mercadoria. Frisa-se, contudo, que essa regra é válida durante uma operação de venda entre dois Estados desde que o comprador seja o consumidor final; caso contrário, incidirá parcialmente no Estado de origem e parcialmente no destinatário que a adquiriu e irá revendê-la, conforme já explicado anteriormente.

\subsubsection{A não cumulatividade do imposto e suas consequências}

O princípio da não cumulatividade, ou, simplesmente, a não cumulatividade, é característica essencial do ICMS, operando mediante técnicas de abatimento, com o escopo de alcançar uma neutralidade da incidência do imposto na cadeia produtiva.

Reiterando de maneira simplificada, dizer que o ICMS é um imposto não cumulativo significa dizer que, ainda que incida em cada operação de mercancia ou prestação de serviço, sobre cada uma dessas operações é deduzido o valor correspondente aos montantes cobrados nas operaçōes e prestaçôes anteriores. Assim, além de constituir uma propriedade do imposto, a não cumulatividade é garantia e direito de crédito do contribuinte.

Porém, como a Lei Complementar 87/96 36 adota a apuração por período de tempo esse direito de crédito, fruto da não cumulatividade, independe da efetiva cobrança do imposto que incidiu nas prestações ou operaçôes anteriores. Nas palavras de Carrazza ${ }^{37}$, o direito de crédito nasce quando resta configurada a

\footnotetext{
36 "Art. 24. A legislação tributária estadual disporá sobre o período de apuração do imposto. As obrigações consideram-se vencidas na data em que termina o período de apuração e são liquidadas por compensação ou mediante pagamento em dinheiro como disposto neste artigo: I as obrigações consideram-se liquidadas por compensação até o montante dos créditos escriturados no mesmo período mais o saldo credor de período ou períodos anteriores, se for o caso; II - se o montante dos débitos do período superar o dos créditos, a diferença será liquidada dentro do prazo fixado pelo Estado; III - se o montante dos créditos superar os dos débitos, a diferença será transportada para o período seguinte."

37 CARrAZZA, Roque Antônio. ICMS. 14. ed. São Paulo: Malheiros, 2009, p. 359.
} 
incidência tributária sobre uma prestação ou operação anterior. Portanto, conforme assevera o autor, a expressão "montante cobrado", presente na segunda parte do artigo $155, \$ 2$, I da Constituição Federal ${ }^{38}$, deve ser juridicamente entendida como montante devido, e não, como montante efetivamente cobrado.

O Supremo Tribunal Federal, no julgamento do Recurso Extraordinário 161.257/SP, pacificou que a concretização do princípio da não cumulatividade é viabilizada pela "existência de uma conta de créditos e débitos, a ensejar acertos em épocas próprias" 39 , considerando que os débitos provenientes da saída de mercadorias ou serviços em um determinado lapso temporal são compensados com os créditos das entradas ocorridas no mesmo período.

Tendo como referência os escritos de Ricardo Alexandre, esse mecanismo de débitos e créditos pode ser sucintamente explicado da seguinte maneira: sempre que o sujeito realiza uma aquisição tributada de mercadoria, ele deve registrar como crédito o valor incidente na operação. Esse valor, entendido como "direito" do contribuinte, denominado pelos contabilistas de "ICMS a recuperar", pode ser abatido do montante incidente nas operações subsequentes. Da mesma forma, toda vez que o sujeito realiza uma alienação tributada de mercadoria, ele deve registrar como débito o valor incidente na operação. Esse valor é uma obrigação do contribuinte, consistente no dever de recolher o valor devido aos cofres públicos estaduais ou compensá-lo com os créditos obtidos nas operações anteriores, chamado na contabilidade de "ICMS a recolher"

Então, a cada período previsto na legislação, faz-se uma comparação entre os débitos e créditos. Caso os débitos sejam superiores aos créditos, o contribuinte deve recolher a diferença aos cofres públicos, caso o valor dos créditos sejam superiores, é possibilitado ao contribuinte algumas opções a depender da legislação aplicável. Geralmente essa diferença pode ser compensada posteriormente, mas existem leis estaduais que preveem, por exemplo, a possibilidade das transferências do crédito, ou, até mesmo, seu ressarcimento.

38 Art. 155, “ $\$ 2^{\circ} \mathrm{O}$ imposto previsto no inciso II atenderá ao seguinte: I - será não cumulativo, compensando-se o que for devido em cada operação relativa à circulação de mercadorias ou prestação de serviços com o montante cobrado nas anteriores pelo mesmo ou outro Estado ou pelo Distrito Federal; (...)".

39 STF, RE 161.257/SP. Rel. Min. Marco Aurélio, DJ 17.04.1998, p. 16.

40 ALEXANDRE, Ricardo. Direito tributário esquematizado. 9. ed. rev., atual. e ampl. Rio de Janeiro: Forense; São Paulo: Método, 2015, p. 47. 
•• Tributação, direitos fundamentais e desenvolvimento

No que tange às exceções ao princípio já mencionadas no tópico anterior, o efeito de recuperação e a regra de reversão, previstas nas alíneas do inciso II do $₫ 2^{\circ}$ do art. 155, são mandamentos que apenas serão aplicados nas hipóteses em que exista uma isenção ou uma não incidência do imposto, sendo imprescindível que esta, não ocorra no início ou no fim do ciclo da circulação da mercadoria. Isso porque, apenas ocorrendo no meio do ciclo será possível que o crédito deixe de ser compensado e seja anulado apenas em relação às operações imediatamente anteriores ou posteriores, evitando, assim, uma indesejada acumulação do tributo ou, ainda, uma carga tributária ao consumidor final inferior a suposta carga que haveria caso ali houvesse uma incidência monofásica do imposto.

Levando em consideração esses efeitos, Vittorio Cassone ${ }^{41}$ entende que a não cumulatividade é uma expressão do princípio da capacidade contributiva, pois, além de vedar que em cada operação o imposto se torne cada vez mais oneroso, impede que a mercadoria ou serviço chegue, ao final do processo econômico, com preços absurdos a serem arcados pelo consumidor.

Logo, ao estabelecer do princípio da não cumulatividade do ICMS, o legislador beneficiou tanto o contribuinte de direito, quanto o consumidor, contribuinte de fato, que deixou de suportar a carga excessiva de tributos calculados cumulativamente sobre toda a cadeia econômica, conforme ocorria no passado com o IVC.

\subsection{O princípio da origem e do destino na tributação sobre o consumo}

É fundamental que o governo de um país organizado sob a forma federativa, ao conferir aos Estados membros a competência para instituir impostos sobre o consumo, defina qual princípio regerá esses eventuais tributos cobrados.

A questão da incidência tributária na origem ou no destino é de suma importância no contexto da tributação do ICMS no Brasil e tema de muitas discussões no âmbito doutrinário e jurisprudencial, pois, são esses os princípios que definem qual Estado arrecadará o tributo, e, conforme anteriormente citado, o ICMS é o imposto responsável pela maior parte da arrecadação tributária no âmbito estadual.

41 Cf. CASSONE, Vittorio. Direito tributário: fundamentos constitucionais da tributação, definição dos tributos e suas espécies, conceito e classificação dos impostos, doutrina, prática e jurisprudência. Vittorio Cassone; prefácio de Ives Gandra da Silva Martins. 18. ed. São Paulo: Atlas, 2007. 
Com a adoção do princípio do destino, bens e serviços são tributados onde são consumidos, ao passo que, aplicar o princípio da origem significa dizer que é devedor do imposto o Estado que produz a mercadoria ou efetua o serviço. No Brasil, pode-se considerar que foi adotado um critério misto de cobrança.

Visando a integração econômica do Brasil com o comércio internacional e com o escopo dos produtos nacionais concorrerem em igualdade de condiçōes com os produtos estrangeiros, aplica-se o princípio do destino tanto nas operações interestaduais quanto nas operações externas, sendo que, neste último caso, as importações estão sujeitas ao mesmo sistema de tributação do que os produtos nacionais, enquanto as exportações são desoneradas.

Para estudiosos como Misabel Derzi ${ }^{42}$ a adoção do princípio da origem é a mais correta, pois garante que o Brasil mantenha um mercado nacionalmente integrado ao permitir a livre circulação de pessoas, bens e serviços entre os Estados, evitando, assim, a existência de fronteiras e alfândegas entre os Estados membros, bem como a discriminação de mercadorias e serviços considerando sua procedência ou destino, nos moldes estabelecidos no artigo 152 da Constituição Federal.

Entretanto, para a autora, a adoção do referido princípio não deixa de ser uma forma complexa que exige, ao ser aplicado em todo o território nacional, uma significativa limitação das competências estaduais, combinada a um grande controle interno sobre os incentivos fiscais, definição das alíquotas, entre outros, sob pena de gerar distorções no mercado, afastar a neutralidade e fomentar a guerra fiscal ${ }^{143}$.

Ives Gandra ${ }^{44}$ vai de encontro com esse entendimento em defesa de que seria desastroso adotar o princípio do destino tendo em vista que "não haveria mecanismo suficientemente eficaz para permitir uma justa compensação, fiscalizações adequadas se não houver qualquer benefício para o Estado fiscalizador, devendo o Estado destinatário ficar sujeito à boa vontade do Estado de origem" para realizar

42 DERZI, Misabel Abreu Machado. Distorções do princípio da não cumulatividade no ICMS - Comparação com o IVA Europeu. In: I Congresso Nacional da Associação Brasileira de Direito Tributário. Belo Horizonte: Del Rey, 1998, p. 124.

43 Cf. DERZI, Misabel Abreu Machado. Aspectos essenciais do ICMS como imposto de mercado. In: SCHOUERI, Luís Eduardo; ZILVETTI, Fernando Aurélio. Direito tributário: estudos em homenagem a Brandão Machado. São Paulo: Dialética, 1998, p. 129.

44 MARTINS, Ives Gandra da Silva. O princípio da não cumulatividade. In: MARTINS, Ives Gandra da Silva. O princípio da não cumulatividade. São Paulo: RT, 2004, n. 10, Nova Série, p. 59-60. 
•• Tributação, direitos fundamentais e desenvolvimento

a fiscalização, uma vez que permitir a fiscalização do Estado de destino no Estado de origem, encareceria consideravelmente o custo administrativo das empresas.

Para Salvador Cândido Brandão Junior ${ }^{45}$, as fronteiras entre alguns Estados do Brasil é decorrência justamente da adoção tanto do princípio da origem, quanto do destino nas operações interestaduais. Contudo, o autor defende que, mesmo com um controle alfandegário entre os membros da federação, o país não deixa de possuir um mercado nacionalmente integrado.

Nesse sentido, ressalta, ainda, que a adoção do princípio da origem é o que possibilita aos Estados concederem incentivos fiscais para atrair empresas produtoras de bens e serviços, pois caso fosse adotado apenas o princípio do destino, não haveria interesse das empresas em se instalarem em Estados com benefícios fiscais de ICMS, já que sua produção não seria onerada.

Deste modo, resta indiscutível o caráter nacional do ICMS, evidenciado, sobretudo, na influência que o aspecto espacial do tributo tem sobre toda a organização financeira e tributária do país e em como esse fator é determinante a instituição de políticas tributárias em âmbito nacional, visto que a República Federativa do Brasil tem como objetivo fundamental a garantia do desenvolvimento nacional e a redução das desigualdades regionais ${ }^{46}$.

\subsection{Os convênios}

Primeiramente, cabe destacar que no artigo 100 do Código Tributário Nacional, os convênios estão dispostos como normas complementares de direito tributário, sendo, portanto, equiparados às decisóes de órgãos administrativos, às normas complementares das leis, aos tratados, às convenções internacionais e aos decretos. Inobstante, ainda que também estejam subordinados à lei, estes convênios a que o artigo faz referência se diferem dos convênios disciplinados pela Lei Complementar n. $24 / 75$.

Nesse sentido, Luciano Amaro ${ }^{47}$ esclarece que estes convênios citados no CTN "são meros acordos entre as diferentes pessoas políticas com vista à fiscalização ou

45 BRANDÃO JUNIOR, Salvador Cândido. Federalismo e ICMS: Estados-membros em "guerra fiscal”. São Paulo: USP - Faculdade de Direito, 2013, p. 111.

46 "Art. $3^{\circ}$ Constituem objetivos fundamentais da República Federativa do Brasil: (...) II - garantir o desenvolvimento nacional; III - erradicar a pobreza e a marginalização e reduzir as desigualdades sociais e regionais; (...)".

47 AMARO, Luciano. Direito tributário brasileiro. 21. ed. São Paulo: Saraiva, 2016, p. 190. 
arrecadação de tributos, à troca de informaçôes de interesse fiscal", diferente dos convênios previstos na forma da Lei Complementar que são "instrumentos das deliberações a que se refere o artigo 155, $\$ 2^{\circ}$, XII, g, da Constituição, que, verdadeiramente, inovam o direito tributário, ao definir hipóteses de concessão de isenções, benefícios e incentivos fiscais atinentes ao ICMS, ou sua revogação”.

Conforme anteriormente exposto, na reforma tributária instituidora da Emenda Constitucional n. 18/65, na tentativa de eliminar a guerra fiscal nas operaçôes interestaduais existente na vigência do antigo imposto sobre vendas e consignações, aos Estados foi instituído o ICM, imposto de consumo sobre valor agregado. No entanto, essa esperança em extinguir os conflitos no plano do comércio interestadual mediante a adoção da técnica não cumulativa e a definição de uma alíquota teto nestas operações, frustrou-se por completo.

Isso porque, o entrave existente entre os chamados Estados produtores e Estados consumidores adquiriu nova feição pela intensiva utilização do ICM "para atrair indústrias ou outras atividades produtivas, mediante a concessão de estímulos e incentivos que desvirtuam as características básicas do imposto, estabelecendo-se clima de aberta concorrência entre os Estados" 48.

Assim, devido à conjuntura narrada, publicou-se o Ato Complementar n. 34/67 estabelecendo que os Estados e Territórios situados em uma mesma região geoeconômica deveriam celebrar convênios para estruturar uma política comum em matéria de isenções, reduções ou outros favores fiscais relativamente ao ICM. Com esse dispositivo, os convênios passaram a ser exigidos regionalmente, mas, segundo Alcides Jorge Costa ${ }^{49}$ "na prática, as regiōes geoeconômicas foram reduzidas a duas: uma, abrangendo os Estados do Sul, do Sudeste e do Centro-Oeste e outra, os Estados das regiōes Norte e Nordeste".

Neste contexto, a Emenda Constitucional n. 01/69 incluiu o $\$ 6^{\circ}$ ao artigo $23^{50}$ sendo, posteriormente, utilizado como fundamento à publicação da Lei

48 BONILHA, Paulo Celso Bergstrom. IPI e ICM. Fundamentos da técnica não cumulativa. São Paulo: Resenha Tributária, 1979, p. 109.

49 COSTA, Alcides Jorge. ICMS - Natureza jurídica da isenção - Natureza jurídica e função do convênio no âmbito do ICMS. In: Estudos sobre IPI, ICMS e ISS. São Paulo: Dialética, 2009, p. 86.

50 "Art. 23. Compete aos Estados e ao Distrito Federal instituir impostos sôbre [sic]: (...) II operações relativas à circulação de mercadorias, realizadas por produtores, industriais e comerciantes, impostos que não serão cumulativos e dos quais se abaterá nos têrmos [sic] do 
•• Tributação, direitos fundamentais e desenvolvimento

Complementar n. 24/75 que estabeleceu a exigência de celebração de convênios entre todos os Estados para a concessão de isenções.

Frente às circunstâncias narradas foi criado o Conselho Nacional de Política Fazendária - CONFAZ, ao qual foi atribuída a missão de promover o aperfeiçoamento do federalismo fiscal e a conciliação tributária entre os Estados da Federação. Composto por Secretários da Fazenda dos Estados e do Distrito Federal e sob a coordenação do Ministério da Fazenda, o CONFAZ tem "por finalidade promover ações necessárias à elaboração de políticas e harmonização de procedimentos e normas inerentes ao exercício da competência tributária dos Estados e do Distrito Federal" 51 .

A fim de atingir esse intuito, as Secretarias de Fazenda de todos os Estados mantêm uma Comissão Técnica Permanente (COTEPE) que se reúne regularmente com o objetivo de discutir temas em finanças públicas de interesse comum, para que possam ser decididas nas reuniōes periódicas do CONFAZ. Tais decisões são operacionalizadas por meio de convênios, protocolos, ajustes, estudos e grupos de trabalho que, em geral, versam sobre concessão ou revogação de benefícios fiscais do ICMS, procedimentos operacionais a serem observados pelos contribuintes, bem como sobre a fixação da política de Dívida Pública Interna e Externa, em colaboração com o Conselho Monetário Nacional ${ }^{52}$.

Especificamente em relação às isenções, os Estados potencialmente concessores deverão apresentar ao CONFAZ sua proposta de benefício fiscal, para que em reunião do Conselho possa ser considerada por todos os Estados-membros. Caso a proposta seja aceita unanimemente, será celebrado um convênio que, após ratificado por todos os entes, poderá ter eficácia ao contribuinte.

Ressalta-se que, na Constituição Federal de 1988 no artigo 155, § 2º, XII, g, não aparece a expressão "convênios", mas sim "deliberações". A expressão "convênio" aparece no artigo $34, \$ 8^{\circ}$ do ADCT, que conferiu provisoriamente aos

disposto em lei complementar, o montante cobrado nas anteriores pelo mesmo ou por outro Estado. (...) $\$ 6^{\circ}$ As isenções do impôsto [sic] sôbre [sic] operaçõos relativas à circulação de mercadorias serão concedidas ou revogadas nos têrmos [sic] fixados em convênios, celebrados e ratificados pelos Estados, segundo o disposto em lei complementar."

51 ELALI, André. O federalismo fiscal brasileiro e o sistema tributário nacional. São Paulo: MP Editora, 2005, p. 73.

52 CONVÊNIOS ICMS. In: CONFAZ. Ministério da Fazenda. Disponível em: <https://www. confaz.fazenda.gov.br/legislacao/convenios> Acesso em: 9 nov. 2017. 
Estados e Distrito Federal, mediante convênio celebrado na forma da Lei Complementar n. 24/75, a competência para normatizar o ICMS se, no prazo de sessenta dias contados da promulgação da Constituição Federal de 1988, não fosse editada a lei complementar necessária à instituição do imposto, posto que, tal convênio apenas vigoraria enquanto não fosse publicada a referida Lei Complementar.

Segundo Salvador Cândido Brandão Junior ${ }^{53}$, "a diferença entre as expressóes convênio e deliberação consiste no fato de que convênios exigem unanimidade, já que representam um acordo com uma conjugação de interesses e, para isso, necessitam da adesão de todos para a expressão da vontade das partes”. Os convênios, necessariamente representam interesses convergentes, uma vez que todas as declarações de vontade manifestadas no instrumento contratual se integram em direção de um objetivo comum.

Já a expressão deliberações representa um acordo entre partes. Souto Maior Borges $^{54}$, seguindo esse raciocínio, argumenta que as deliberaçôes não contrariam a ideia dos convênios, pois, ambos constituem formas de deliberação multilateral, no entanto, os convênios estão "seguramente inclusos" nas deliberações, até porque, para o autor, seria a forma mais própria de deliberação.

Ratificando a compreensão acima exposta tem-se o artigo $2^{\circ}$ da Lei Complementar 24/75, estabelecendo que os convênios sejam celebrados em reunióes em que tenham sido convocados representantes de todos os Estados e do Distrito Federal, estando a concessão de eventuais benefícios subordinadas à decisão unânime dos Estados representados.

Válido destacar, porém, que os convênios, como norma geral tributária, por si só, não criam qualquer direito, conforme bem destaca Roque Antonio Carrazza ${ }^{55}$ :

Detalhando o assunto, os Estados e o Distrito Federal devem, para conceder isençôes de ICMS, firmar entre si convênios. Não são estes, porém, que as fazem nascer. Apenas integram o processo legislativo necessário à concessão destas desoneraçôes tributárias. Elas surgem - ou deveriam surgir - do decreto legislativo ratificador do convênio interestadual.

53 BRANDĀO JUNIOR, Salvador Cândido. Federalismo e ICMS: Estados-membros em "guerra fiscal". São Paulo: USP - Faculdade de Direito, 2013, p. 94.

54 BORGES, Souto Maior. Incentivos fiscais e financeiros. Revista Trimestral de Direito Público, São Paulo: Malheiros, 1994, n. 8, p. 95-96.

55 CARRAZZA, Roque Antônio. Convênios ICMS e art. 14 da lei de responsabilidade fiscal sua inaplicabilidade - questões conexas. Revista de Estudos Tributários, Porto Alegre, n. 16, 2000, p. 150. 
•• Tributação, direitos fundamentais e desenvolvimento

No mesmo sentido é a doutrina de Geraldo Ataliba ${ }^{56}$ :

(...) o convênio não dá nem tira direito a nenhuma Fazenda e a nenhum contribuinte. Não cria direito de natureza tributária nem em benefício, nem em detrimento de ninguém. É mero pressuposto de exercício eficaz da competência isentadora dos legisladores ordinários estaduais.

\subsubsection{A problemática envolvendo os convênios}

A primeira controvérsia que circunda a temática dos convênios diz respeito à questão da recepção da Lei Complementar n. 24/75 pela Constituição Federal de 1988. A referida lei teve seu texto baseado na Constituição de 1967, sobretudo, na Emenda Constitucional n. 01/69, e foi editada num contexto socioeconômico completamente diferente do que atualmente rege a Constituição de 88.

Paulo de Barros Carvalho ${ }^{57}$ leciona que tratava-se de um "período que se caracterizou pelo autoritarismo extremado e pela predominância do Poder Executivo, reduzido que foi o Poder Legislativo a uma função decorativa”.

Com base nesse argumento o Distrito Federal propôs a Arguição de Descumprimento de Preceito Fundamental (ADPF n. 198) para fins de ver declarada a inconstitucionalidade dos artigos $2^{\circ}, \S 2^{\circ}$ e do artigo $4, \$ 1^{\circ}$ e $\$ 2^{\circ}$ da Lei Complementar. O Distrito Federal reforça que exigir unanimidade dos Estados para a concessão dos benefícios representa uma ofensa direta ao princípio da supremacia da vontade da maioria, bem como à necessária autonomia dos estados federados, violando, assim, os princípios democráticos, bem como o princípio da proporcionalidade.

A arguição foi julgada pelo Ministro Dias Toffoli, relator do processo, e este negou a concessão da liminar amparando-se na própria jurisprudência da Corte, alegando que "os artigos objeto da presente ação encontram-se em vigor há mais de 34 anos, sendo certo que 21 desses anos decorreram já sob a égide da Constituição Federal de 1988. A partir da decisão apresentada, constata-se que costuma ser rigoroso o tratamento dado à disciplina do ICMS por esta Corte, exatamente com o

MATTOS, Aroldo apud Geraldo Ataliba. A natureza e o alcance dos convênios em matéria do ICMS. Revista Dialética de Direito Tributário, v. 79, p. 10.

57 CARVALHO, Paulo de Barros. A concessão de isenções, incentivos ou benefícios fiscais no âmbito do ICMS. In: MARTINS, Ives Gandra da Silva; CARVALHO, Paulo de Barros. Guerra fiscal. Reflexões sobre a concessão de benefícios fiscais no âmbito do ICMS. São Paulo: Noeses, 2012, p. 53. 
escopo de coibir a denominada "guerra fiscal" que Estados-membros costumam travar em matéria de concessões, incentivos e isenções fiscais" 58 .

Outro entendimento é o de Paulo de Barros Carvalho ${ }^{59}$, ao alegar que quando aprovada a lei a Constituição vigente referia-se expressamente aos convênios, porém, advoga que hoje esse pressuposto não deve estar presente com tanta rigidez, sendo completamente admissível mitigá-lo em situações peculiares. Nesse sentido, o autor ressalta que em diversas partes do texto constitucional o termo 'deliberaçôes’ aparece e não está ligado a uma aprovação unânime, como, por exemplo, o artigo 62 que expressa que para haver a conversão da medida provisória em lei ordinária deve anteriormente haver "deliberação" do Congresso Nacional.

Reforçando esse argumento, há o pressuposto de que em uma Federação as decisões, via de regra, devem ser tomadas por maioria, já que seus membros não são dotados de soberania e se submetem a um ordenamento jurídico único. Ou seja, é natural que em um Estado Federal um Estado-membro, eventualmente, se submeta a linhas de atuação que não aprovou. Assim, exigir uma votação unânime entre os Estados é incompatível com o ordenamento jurídico e com a própria natureza do Estado Democrático de Direito, sobretudo, tendo em vista de que não há na Constituição Federal a exigência de unanimidade para aprovação de qualquer medida.

Nessa linha de entendimento, tramitaram no Congresso Nacional o projeto de lei n. 240/2006 e no Senado Federal o projeto n. 85/2010, visando a alteração da Lei Complementar n. 24.

O primeiro projeto propunha a alteração do artigo $2^{\circ}, \$ 2^{\circ}$ para condicionar a aprovação para concessão de isenções, incentivos e benefícios fiscais ao quorum de quatro quintos dos Estados sob a justificativa de que a Lei ultrapassou os limites constitucionais "ferindo de morte a autonomia federativa e praticamente inviabilizando a concessão de benefícios fiscais" ${ }^{60}$.

Em seu relatório, a Comissão de Constituição, Justiça e Cidadania (CCJ) deixou consignado que, apesar da redação da lei estar vigente há mais 30 anos, atualmente o poder de veto individual é um exagero de "interferência na autonomia

58 STF, ADPF 198, Pleno. Rel. Min. Dias Toffoli, DJ 24 nov. 2009.

59 CARVALHO, Paulo de Barros. Direito tributário: fundamentos jurídicos da incidência. 5. ed. São Paulo: Saraiva, 2007, p. 55.

60 Projeto de Lei do Senado n. 240/2006-Complementar. Disponível em: http://www.6.senado. gov.br/mate-pdf/8658.pdf . Acesso em: 14 nov. 2017, p. 2. 
•• Tributação, direitos fundamentais e desenvolvimento

política das demais unidades, principalmente levando em conta que, no limite, será a vontade política de 1/27 (um vinte e sete avos), bloqueando a (...) autonomia somada de 26/27 (vinte e seis vinte e sete avos) dos Estados" ${ }^{\prime \prime}$. Apesar de aprovado pela CCJ, hoje, o projeto encontra-se arquivado.

O segundo projeto sugeria, dentre outras medidas, além da alteração do mesmo artigo para condicionar a aprovação de concessão e revogação de isençôes, incentivos e benefícios fiscais à decisão da maioria absoluta dos Estados e Distrito Federal, a alteração dos incisos I e II do artigo $8^{\circ}$ da Lei, defendendo a existência de uma evidente usurpação do Poder Judiciário, com ofensa à separação dos Poderes, já que os Estados que se sentem prejudicados, com uma concessão unilateral de incentivo fiscal por outro Estado, aplicam uma dupla sanção ao invalidar a lei concessiva do benefício e negar o crédito do valor correspondente ao dispensado na origem.

Sobre a proposta de lei, a Comissão de Assuntos Econômicos (CAE) emitiu um parecer ${ }^{62}$ afirmando que não encontra inconstitucionalidades, mas apresentou uma emenda para exigir, além da aprovação da maioria absoluta dos Estados e do Distrito Federal, que pelo menos um Estado de cada uma das cinco regióes aprove a medida e para que sejam alteradas as políticas sancionatórias das concessões irregulares. Contudo, atualmente o projeto também se encontra arquivado.

O Supremo Tribunal Federal adota entendimento diverso sustentando que a Lei Complementar 24/75 não é incompatível com a Constituição da República. Defende que, na atualidade, para a deliberação relativa à concessão de isenções ou benefícios fiscais, deverá sim haver um consenso entre os Estados e o Distrito Federal, uma vez que a aprovação do convênio só é possível mediante uma decisão unânime $e^{63}$.

Só em junho de 2011, o Plenário julgou procedentes quatorze ações diretas de inconstitucionalidade ${ }^{64}$, nas quais manifestou seu entendimento no sentido da im-

${ }_{61}$ Parecer da Comissão de Constituição, Justiça e Cidadania, sobre o Projeto de Lei do Senado n. 240, de 2006 - Complementar. Disponível em: <http://www.senado.gov.br/atividade/materia/getPDF.asp?t=23404\&tp=1>. Acesso em: 14 nov. 2017, p. 4.

62 Parecer da Comissão de Assuntos Econômicos, sobre o Projeto de Lei do Senado n. 85, de 2010 - Complementar. Disponível em: <http://www.6.senado.gov.br/mate-pdf/78762.pdf>. Acesso em: 14 nov. 2017.

63 STF, ADIN 2157-5, Pleno. Rel. Min. Moreira Alves, 28.06.2000.

64 ADI n. 2906-RJ; ADI n. 2375-RJ; ADI n. 3674-RJ; ADI n. 3413-RJ; ADI n. 4457-RJ; ADI n. 3794-PR; ADI n. 2688-PR; ADI n. 1247-PA; ADI n. 3702-ES; ADI n. 4152-SP; ADI n. 3664-RJ; ADI n. 3803-PR; ADI n. 2549-DF; ADI n. 2345-SC. 
possibilidade de concessão unilateral de incentivos fiscais por ofensa ao art. 155, $\$ 2^{\circ}$, XII, $g$, da Constituição Federal.

Procurando solucionar com maior eficiência os pleitos de inconstitucionalidade de lei dos Estados sobre o tema, o STF elaborou a proposta de Súmula Vinculante n. 69, com o seguinte teor: "qualquer isenção, incentivo, redução de alíquota ou base de cálculo, crédito presumido, dispensa de pagamento ou outro benefício fiscal relativo ao ICMS, concedido sem prévia aprovação em convênio celebrado no âmbito do CONFAZ, é inconstitucional".

Entretanto, quanto a aprovação da súmula surge a preocupação em relação aos seus efeitos, tendo em vista que, via de regra, esta declaração de inconstitucionalidade possui efeitos erga omnes e ex tunc, operando retroativamente, tornando nulo seus efeitos desde a edição da lei declarada inconstitucional ${ }^{65}$. Assim, a preocupação se concentra na situação dos contribuintes, que observam a lei publicada pelo seu Estado, lei esta que goza de presunção de validade, bem como na situação relativa aos créditos fiscais. Porém não cabe aqui, discutir com maior profundidade essa temática.

Seguindo a compreensão da Suprema Corte, Ives Gandra defende que, seguindo esses argumentos é preciso verificar se a concessão de incentivos fiscais no âmbito do ICMS é uma questão constitucional fundamental, já que ligado ao princípio federativo. $\mathrm{O}$ autor afirma que a exigência de unanimidade nas deliberações dos Estados e do Distrito Federal "decorre de não ter o constituinte estabelecido quorum menor para aprovação dos estímulos fiscais, sustentando que a dicção do artigo 155, $\$ 2$ ' XIII, g, fala em Estados e Distrito Federal, "o que representa unanimidade, pois não oferta exceções deliberativas, nem a possibilidade de exclusōes" ${ }^{\prime 66}$.

Por essa razão, com base apenas na Constituição Federal, Gandra entende que não respeitar a unanimidade prevista constitucionalmente acarreta ofensa à livre

65 "A declaração de nulidade situa-se no plano da validade do ato jurídico: é a sanção pela invalidade da norma. Como consequência, a lei ou ato normativo nulo não deverá mais produzir efeitos: passa-se, assim, ao plano da eficácia, que deverá ser paralisada. Nulidade e ineficácia, portanto, são as consequências que, de regra, resultarão da declaração de inconstitucionalidade”. (BARROSO, Luís Roberto. Controle de constitucionalidade de direito brasileiro. 3. ed. São Paulo: Saraiva, 2008, p. 190).

${ }_{66}$ MARTINS, Ives Gandra da Silva. Estímulos fiscais no ICMS e a unanimidade constitucional. In: Concessão de Benefícios Fiscais no âmbito do ICMS. São Paulo: Noeses, 2012, p. 6-7. 
•• Tributação, direitos fundamentais e desenvolvimento

concorrência prevista no artigo 170, IV, à isonomia prevista no artigo 150, II e à atribuição constitucional de que só a União pode estabelecer incentivos fiscais para promover o equilíbrio do desenvolvimento socioeconômico entre as diferentes regiôes, nos termos do artigo 151, I. Portanto, concluiu que a Lei Complementar n. 24/75 foi recepcionada pela Constituição Federal e que, a unanimidade, é princípio fundamental destinado a preservar a Federação e, assim sendo, cláusula pétrea ${ }^{67}$.

De igual modo, Paulo de Barros Carvalho ${ }^{68}$ não contesta a constitucionalidade da Lei Complementar e em seu discurso também é possível vislumbrar a compreensão de que a lei foi recepcionada pela Constituição Federal de 1988. Entretanto, em relação à unanimidade, o autor acredita que esta não deva ser tratada com tamanha rigidez, como sustenta Ives Gandra, principalmente se for considerada a existência de unidades federativas em situação precária de desenvolvimento.

Assim, Paulo de Barros propõe que, em casos de notória desigualdade, o quorum seja alterado para dois terços, de forma a possibilitar o estímulo ao desenvolvimento de Estados menos favorecidos e a consequente redução das desigualdades regionais, já que a exigência de unanimidade praticamente inviabiliza a faculdade do uso de incentivos e benefícios fiscais.

Outro problema envolvendo os convênios diz respeito à questão da ratificação destes. Para a maioria doutrinária, possuem natureza autorizativa, exigindo, portanto, a edição de uma lei posterior em cada Estado para que seja possível e legítima a efetiva concessão do incentivo.

$\mathrm{O}$ artigo 150, $\$ 6^{\circ}$ da Constituição Federal prescreve "que qualquer subsídio ou isenção, redução de base de cálculo, concessão de crédito presumido, anistia ou remissão relativos a impostos, taxas ou contribuições, só poderá ser concedido mediante lei específica, federal, estadual ou municipal, que regule exclusivamente as matérias acima enumeradas ou o correspondente tributo ou contribuição, sem prejuízo do disposto no art. $155, \$ 2^{\circ}$, XII, $g$ ”.

O conflito surge a partir da leitura do artigo $4^{\circ}$ da Lei Complementar $n$. 24/75 que dispõe que, no "prazo de 15 (quinze) dias contados da publicação dos

MARTINS, Ives Gandra da Silva. Ibidem, p. 13-17.

68 CARVALHO, Paulo de Barros. A concessão de isenções, incentivos ou benefícios fiscais no âmbito do ICMS. In: MARTINS, Ives Gandra da Silva; CARVALHO, Paulo de Barros. Guerra fiscal. Reflexões sobre a concessão de benefícios fiscais no âmbito do ICMS. São Paulo: Noeses, 2012, p. 56-57. 
convênios no Diário Oficial da União, e independentemente de qualquer outra comunicação, o Poder Executivo de cada Unidade da Federação publicará decreto ratificando ou não os convênios celebrados, considerando-se ratificação tácita dos convênios a falta de manifestação".

Complementando a disposição, o artigo $7^{\circ}$ da Lei prescreve que a ratificação do convênio torna sua obediência obrigatória para todos os Estados, inclusive aqueles que mesmo convocados, não compareceram na reunião do CONFAZ.

Sobre a questão, Alcides Jorge Costa ${ }^{69}$ ensina que, antes de vigorar a Constituição de 1967, foi baixado o Ato Complementar n. 34/1967 que dispunha em seu artigo $1^{\circ}, \$ 2^{\circ}$ que "os convênios e protocolos independem de ratificação pelas assembleias legislativas dos estados participantes", porém explica que este ato complementar, bem como a Lei Complementar foram publicados em um período caracterizado pelo autoritarismo extremo e pela predominância do Poder Executivo, o que justifica essa postura antidemocrática.

O tributarista complementa que caso se admita a constitucionalidade do artigo $4^{\circ}$ da lei, inclusive com a previsão de ratificação tácita, os convênios passarão a ter força de lei interna em cada Estado da Federação. Sustenta, nessa linha, que não haverá espaço para sustentar a existência de convênios autorizativos, já que, por estar ratificado, o próprio convênio já concede a isenção.

Por fim, concluiu que "os convênios concedem isenções, mas não podem autorizar que um ou mais Estados, a critério de cada qual, concedam isençôes"70, uma vez que ao exigir votação unânime e admitir ratificação tácita, a lógica do sistema se justifica para admitir a natureza impositiva dos convênios, na medida em que o Estado que não concordar com a concessão de determinada isenção ou benefício, poderá usar de seu direito de veto durante a reunião em que se discutir o convênio ou, posteriormente, através de não ratificação expressa ${ }^{71}$.

Importante verificar que, embora considere que essa parte do dispositivo foi recepcionada, Alcides ${ }^{72}$ compreende como inconstitucional a outorga de poderes aos Executivos estaduais para a ratificação desses instrumentos. O autor interpreta

69 COSTA, Alcides Jorge. ICM na Constituição e na lei complementar. São Paulo: Resenha Tributária, 1978, p. 316-317.

70 COSTA, Alcides Jorge. Ibidem, p. 339.

71 COSTA, Alcides Jorge. Ibidem, p. 128.

72 COSTA, Alcides Jorge. Ibidem, p. 130. 
•• Tributação, direitos fundamentais e desenvolvimento

essa postura como de "excessiva centralização" do Poder Executivo, defendendo que a celebração de convênios deve ser um procedimento prévio que funcione como um verdadeiro limitador da competência das Assembleias Legislativas, mas sem, contudo, eliminá-las.

Geraldo Ataliba ${ }^{73}$ também defendia a inconstitucionalidade deste dispositivo da Lei Complementar n. 24 e, com fundamento no artigo 153, $\$ 2^{\circ}$ da Constituição de 1967 ensinava que "a reserva de convênio não exclui reserva de lei. (...) caso isto fosse possível, derrogado estaria o princípio da legalidade da tributação e vulnerado o arquiprincípio da separação dos Poderes, pressupostos da República e do Estado do Direito”.

Souto Maior Borges ${ }^{74}$, por sua vez, afirma que, a rigor, a ratificação deveria ocorrer mediante lei estadual, mas, como "lei estadual é ato unilateral do Estado-membro, este não pode diretamente fazê-lo, dado que se trata de ato plurilateral. E porque à lei não é possível fazê-lo, resta o convênio como sub-rogado excepcional da legalidade".

Para Paulo de Barros Carvalho ${ }^{75}$ os convênios interestaduais apesar de possuírem natureza autorizativa "não são portadores de força vinculante", em virtude da própria autonomia legislativa conferida constitucionalmente aos Estados. Conclui que a ratificação dos acordos seria matéria de competência exclusiva das Assembleias Legislativas estaduais dada a "similaridade com o processo de aprovação de tratados, acordos ou atos internacionais que acarretem encargos ou compromissos gravosos ao patrimônio nacional."76.

No mesmo estudo Paulo de Barros $^{77}$ reconhece o caráter prévio dos convênios para a concessão de incentivos fiscais de ICMS, argumentando que a concessão destes incentivos não é realizada por meio de convênios, conforme segue:

73 ATALIBA, Geraldo. Eficácia dos convênios para isenção do ICM. Revista de Direito Tributário, São Paulo: RT, n. 11 e 12 1980, p. 110.

74 BORGES, José Souto Maior. Sobre as isenções, incentivos e benefícios fiscais relativos ao ICMS. Revista Dialética de Direito Tributário, São Paulo: Dialética, n. 6, 1996, p. 73.

75 CARVALHO, Paulo de Barros. Curso de direito tributário. 23. ed. São Paulo: Saraiva, 2010, p. 54.

76 COSTA, Alcides Jorge. ICM. Isençōes. Convênios. In: Direito tributário atual. São Paulo: Resenha Tributária, 1983, p. 88.

77 CARVALHO, Paulo de Barros. A concessão de isenções, incentivos ou benefícios fiscais no âmbito do ICMS. In: MARTINS, Ives Gandra da Silva; CARVALHO, Paulo de Barros (Coord.). Guerra Fiscal. Reflexões sobre a concessão de benefícios fiscais no âmbito do ICMS. São Paulo: Noeses, 2012, p. 62-63. 
(...) esses instrumentos, firmados segundo o procedimento estabelecido em lei complementar e fundados no artigo 155, $\$ 2^{\circ}$, XII, “g”, da Constituição de 1988 são etapa que antecede o conjunto de providências legiferantes por meio das quais hão de ser introduzidas.

Para sustentar seu entendimento, o autor demonstra a compreensão do Supremo Tribunal Federal exposta na ADI n. 1247-PA, que consigna que os regramentos e princípios constitucionais aplicados ao ICMS justificam a edição de lei complementar destinada a regular o modo e a forma como os Estados-membros e o Distrito Federal, "sempre após deliberação conjunta, poderão, por ato próprio, conceder e/ou revogar isençôes, incentivos e benefícios fiscais"78.

A Suprema Corte, sobre o tema também se manifestou no julgamento do Recurso Extraordinário n. 539.130/RS ${ }^{79}$, assim proferindo sua decisão:

DIREITO CONSTITUCIONAL E TRIBUTÁRIO. RECURSO EXTRAORDINÁRIO. CONVÊNIO ICMS 91/91. ISENÇÃO DE ICMS. REGIME ADUANEIRO ESPECIAL DE LOJA FRANCA. "FREE SHOPS" NOS AEROPORTOS. PROMULGAÇÃO DE DECRETO LEGISLATIVO. ATENDIMENTO AO PRINCÍPIO DA LEGALIDADE ESTRITA EM MATÉRIA TRIBUTÁRIA. 1. Legitimidade, na hipótese, da concessão de isenção de ICMS, cuja autorização foi prevista em convênio, uma vez presentes os elementos legais determinantes para vigência e eficácia do benefício fiscal. 2. Recurso extraordinário conhecido, mas desprovido.

O recurso em análise teve seu provimento negado na medida em que a Assembleia Legislativa do Estado ratificou o Convênio 91/91 por meio do Decreto Legislativo n. 6.591/92, sem ofensa, portanto, ao $₫ 6^{\circ}$ do artigo 150 da Constituição Federal, que exige a edição de lei específica para a concessão de incentivos sem prejuízo do artigo $155, \$ 2$, XII, "g".

O Ministro Joaquim Barbosa, ao analisar em seu voto o artigo, defendeu que a garantia da regra da legalidade não é excluída imediatamente pela regra que busca assegurar harmonia no âmbito da Federação e que, desta forma, o Poder Legislativo não pode delegar ao Executivo a escolha final sobre a concessão ou não do benefício, entendendo, pois, que "admitir a ratificação tácita dos convênios, elaborados com a participação apenas de representantes do Poder Executivo, supóe ter-se por válida a própria concessão do benefício por ato oriundo apenas do Chefe do Poder Executivo" 80 .

\footnotetext{
78 STF, ADI 1247-MC-PA, Pleno, Rel. Min. Celso de Mello, DJ 8.9.1995.

79 STF, RE 539130-RS, Segunda Turma, Rel. Min. Ellen Gracie, DJ 4.12.2009.

80 STF, RE 539130-RS, Segunda Turma, Rel. Min. Ellen Gracie, DJ 4.12.2009, p. 5.
} 
•• Tributação, direitos fundamentais e desenvolvimento

Sendo assim, para o STF, o convênio é apenas pressuposto à concessão da isenção do ICMS, que, com caráter meramente formal, deve, evidentemente, respeitar os princípios e normas constitucionais, inclusive a ratificação pelo Legislativo estadual.

\section{OPERAÇÕES INTERESTADUAIS}

As alíquotas interestaduais surgiram, com a Emenda Constitucional n. 18/65, na Constituição Federal de 1946, visando solucionar o problema entre Estados ditos importadores e exportadores que vigorava com o então vigente IVC, imposto que, conforme anteriormente salientado, também era de competência estadual e plurifásico, porém cumulativo.

O IVC em operações interestaduais era devido somente na origem, e consequentemente lhe era aplicada somente a alíquota interna daquele Estado produtor. Essa situação fez com que os Estados ditos consumidores pleiteassem uma reforma por entenderem que acabavam transferindo renda aos Estados produtores.

A comissão que elaborou o projeto de reforma tributária confiou que a solução seria estabelecer uma alíquota máxima interestadual, de forma a acabar com as desigualdades existentes entre os Estados operadores.

Nesse diapasão, a Constituição Federal de 1988 passou a disciplinar, em seu artigo $155, \$ 2^{\circ}$, VII, que em relação às operações ou prestações interestaduais de bens ou serviços destinados ao consumidor final, contribuinte ou não do imposto, será aplicada no destino a diferença entre a alíquota interna do Estado destinatário e a alíquota interestadual.

Assim, nas operações interestaduais entre contribuintes do imposto, seja ele consumidor final ou não, utiliza-se uma forma híbrida de repartição da arrecadação do ICMS entre os Estados envolvidos na operação responsável pelo fato gerador do imposto, de forma a evitar que os Estados produtores transfiram renda aos Estados consumidores, e vice-versa.

Ademais, a Constituição de 1988, ao instituir o artigo 155 , $\$ 2$, VIII, estabelecendo que a alíquota interestadual deve ser inferior à alíquota interna, acabou por conferir ao Estado destinatário, quando é consumidor final e contribuinte do imposto, o direito de cobrar a diferença entre a sua alíquota interna e a interestadual recolhida na origem.

Desta forma, pode-se considerar que foi adotado "um misto de princípio da origem e princípio do destino para fins de operações interestaduais, quando o 
adquirente não é consumidor final" ${ }^{81}$, para que fosse possível a repartição de receitas do ICMS entre os Estados produtores e consumidores, o que, segundo Derzi ${ }^{82}$ não só produz evasões e elisões planejadas, como também não contempla as diferenças peculiares entre Estados que integram a mesma região.

Todavia, compartilhando do entendimento de Antônio Carlos Rodrigues do Amaral $^{83}$, nota-se que essa sistemática de repartição de arrecadação entre Estados e a aplicação da não cumulatividade, constitui um regime complexo e inconveniente, que continua a gerar desigualdades pela incidência na origem e, principalmente, fomentando a guerra fiscal existente entre os entes.

A seguir, estão ilustradas três situações hipotéticas que demonstram o quanto na prática não se apresenta completamente eficiente o regime de alíquotas do ICMS quando o Estado destino é também consumidor final da mercadoria e contribuinte do imposto:

Primeiramente, cabe analisar a regra normal de incidências nas operações interestaduais, em que há uma transferência das receitas entre os Estados. Considere-se uma operação interestadual em que o Estado de origem arrecada $12 \%$ e o Estado de destino, em respeito ao princípio da não cumulatividade, ao reconhecer esse montante cobrado, arrecada a diferença entre esses $12 \%$ e sua alíquota interna de $20 \%$, totalizando efetivos $8 \%$. Veja o exemplo na tabela a seguir:

\begin{tabular}{|l|c|c|}
\hline \multirow{2}{*}{} & Estado de origem (A) & Estado de destino (B) \\
\cline { 2 - 3 } & \multicolumn{2}{|c|}{ Consumo } \\
\hline Operação & 100 & 200 \\
\hline Alíquota & $12 \%$ & $20 \%$ \\
\hline Tributo & 12 & 40 \\
\hline Crédito & 0 & 12 \\
\hline Resultado & 12 & 28 \\
\hline
\end{tabular}

81 AMARAL, Antônio Carlos Rodrigues do. O imposto sobre o valor agregado. São Paulo: Editora Rumo, 1995, p. 69.

82 DERZI, Misabel Abreu Machado. Aspectos essenciais do ICMS como imposto de mercado. In: SCHOUERI, Luís Eduardo; ZILVETTI, Fernando Aurélio (Coord.). Direito tributário: estudos em homenagem a Brandão Machado. São Paulo: Dialética, 1998, p. 131.

83 AMARAL, Antônio Carlos Rodrigues do. Op. cit., p. 69. 
•• Tributação, direitos fundamentais e desenvolvimento

De maneira simplificada, como na etapa da circulação destinada ao consumidor do Estado destino (B) haverá um efeito de recuperação, em razão do crédito menor do que seria caso incidisse apenas a alíquota interna, será recolhido $\mathrm{R} \$$ 28,00 em razão do abatimento do valor o crédito proveniente da etapa anterior, na qual já incidiu a alíquota do Estado de origem (A). Destaca-se que, o Estado de destino (B), na operação destinada ao consumidor final, aplicou uma alíquota efetiva de $14 \%$, já que um montante foi arrecadado pelo Estado de origem (A) na operação interestadual anterior.

Caso a operação anterior fosse interna, ou seja, a incidência do imposto se desse no Estado de destino, a alíquota efetiva no consumo seria de $10 \%$, já que, como não haveria crédito a ser descontado, a alíquota do imposto incidiria sobre o valor inicial da mercadoria ou do serviço e não sobre o valor do consumo. Seriam recolhidos, portanto, $\mathrm{R} \$ 20,00$ e não $\mathrm{R} \$ 28,00$.

Sendo assim, conclui-se que o Estado destino de fato arrecadou $\mathrm{R} \$ 8,00 \mathrm{em}$ sua operação interestadual, pois, caso a operação fosse interna haveria a incidência de sua alíquota de $20 \%$ sobre os $\mathrm{R} \$ 100,00$, e como não haveria crédito de operação anterior a ser compensado sua arrecadação, de fato, seria de $\mathrm{R} \$ 20,00$.

Outra possibilidade ocorre na hipótese de concessão de benefício fiscal pelo Estado de origem, no caso desse benefício ser aprovado através de convênio. Neste caso, o Estado destino, acaba recolhendo o valor total de sua alíquota efetiva, pois não há crédito na operação isenta, desencadeando, em uma eventual operação subsequente ao consumidor final, o mesmo efeito de recuperação. Conforme exemplificado:

\begin{tabular}{|l|c|c|}
\hline \multirow{2}{*}{} & \multicolumn{2}{|c|}{ Consumo } \\
\cline { 2 - 3 } & 100 & 200 \\
\hline Operação & Benefício & $20 \%$ \\
\hline Alíquota & 0 & 40 \\
\hline Tributo & 0 & 0 \\
\hline Crédito & 0 & 0 \\
\hline Resultado & 0 & \multicolumn{2}{|c|}{} \\
\hline
\end{tabular}


O problema ocorre quando o Estado de origem (A) concede o benefício fiscal, sem a celebração e aprovação do convênio, e devolve o montante do imposto pago pelo contribuinte. Neste caso, como o benefício não foi aprovado legalmente, o Estado de destino (B) desconsidera a isenção concedida e mantém sua alíquota, bem como o crédito que deveria existir na hipótese em que não há incentivo algum. Assim, o Estado destino nessa operação interestadual, arrecada o mesmo montante correspondente à diferença com sua alíquota interna, ou seja, $\mathrm{R} \$ 8,00$.

\begin{tabular}{|l|c|c|}
\hline \multirow{2}{*}{} & \multicolumn{2}{|c|}{ Consumo } \\
\cline { 2 - 3 } & 100 & 200 \\
\hline Operação & 12 & $20 \%$ \\
\hline Alíquota & 12 & 40 \\
\hline Tributo & 0 & 12 \\
\hline Crédito & 12 & - \\
\hline Benefício & 0 & 28 \\
\hline Resultado & 0 & \multicolumn{2}{|c|}{} \\
\hline
\end{tabular}

A Constituição prevê em seu artigo $155, \$ 2^{\circ}$, II o efeito de recuperação em caso de benefício fiscal. No entanto, "na operação com incentivo fiscal não há crédito e ainda é preciso estornar o crédito das etapas anteriores" ${ }^{34}$. A própria Lei Complementar n. $24 / 75$ disciplina em seu artigo $8^{\circ}$, I, que é sem efeito o crédito fiscal fruto de benefício sem a celebração de convênio.

É importante ressaltar que a ressalva feita no dispositivo constitucional supramencionado, autorizando a legislação a excepcionar a anulação do crédito das etapas anteriores, a fim de permitir a apropriação do crédito na operação incentivada, representa um crédito presumido e só pode ser interpretada à luz da alínea "g", do inciso XII, do $₫ 2^{\circ}$ do artigo 155, que determina a deliberação dos Estados e do Distrito Federal para a concessão de benefício fiscal.

84 BRANDÃO JUNIOR, Salvador Cândido. Federalismo e ICMS: Estados-membros em "guerra fiscal". São Paulo: USP - Faculdade de Direito, 2013, p. 114. 
-. Tributação, direitos fundamentais e desenvolvimento

Portanto, o terceiro exemplo dado é juridicamente incorreto, porque ainda que se considere que do ponto de vista arrecadatório o Estado de destino arrecade o mesmo montante, autores como Ives Gandra ${ }^{85}$ sustentam que a situação gera prejuízos ao Estado destino, uma vez que recebendo a mercadoria incentivada é obrigado a conceder o respectivo crédito fiscal em respeito ao princípio constitucional da não cumulatividade do imposto. Nota-se que o Estado destinatário da mercadoria, nesta situação, acaba suportando o incentivo que foi concedido, mesmo que sem sua autorização ou consenso.

O problema desse comportamento muito comum entre os Estados membros, é que são gerados prejuízos não somente a economia do Estado destinatário da mercadoria ou do serviço, que deixa de arrecadar o montante total da alíquota aplicada. Essa prática também afeta diretamente os contribuintes - tanto os que aceitam o incentivo fiscal que não foi aprovado por convênio, quanto os que recebem o bem proveniente deste contribuinte que recebeu o incentivo fiscal - porque poderão arcar com as consequências administrativas e jurídicas pelo pagamento irregular.

Não obstante, a situação ainda se agravada caso a operação subsequente à operação interestadual destinar-se ao exterior. Pelo mandamento constitucional prescrito no art. 155, $\$ 2^{\circ}, \mathrm{X}$, “a”, no qual a Carta Magna garante imunidade tributária do ICMS nas exportações, bem como a manutenção e utilização de todo o imposto pago nas etapas anteriores, aplica-se nessa operação o princípio do destino, desonerando as exportaçôes e assegurando a manutenção e o aproveitamento do montante cobrado nas operações anteriores.

Logo, caso haja uma operação interestadual precedendo à de exportação, nas palavras de Salvador Cândido, haverá distorçôes "na medida em que, enquanto o Estado de origem arrecadou uma parcela do tributo na operação, o Estado de destino desta operação interestadual é obrigado a devolver o montante integral do imposto ao exportador sem nada ter arrecadado" $"$.

Assim, o Estado de destino da operação interestadual deverá devolver ao contribuinte o montante recolhido nas etapas anteriores como medida de desoneração das exportações, caso na operação seguinte o contribuinte realize uma exportação. Conforme explicado na tabela exemplificativa a seguir:

\footnotetext{
MARTINS, Ives Gandra da Silva. Estímulos fiscais no ICMS e a unanimidade constitucional. In: Concessão de Benefícios Fiscais no âmbito do ICMS. São Paulo: Noeses, 2012.

86 BRANDÃO JUNIOR, Salvador Cândido. Federalismo e ICMS: Estados-membros em "guerra fiscal”. São Paulo: USP - Faculdade de Direito, 2013, p. 116.
} 
Federalismo fiscal $\quad \bullet$

\begin{tabular}{|c|c|c|}
\hline & Estado de origem (A) & Estado de destino $(B)$ \\
\hline & \multicolumn{2}{|c|}{ Exportação } \\
\hline Operação & 100 & 200 \\
\hline Alíquota & $12 \%$ & Imunidade \\
\hline Tributo & 12 & 0 \\
\hline Crédito & $\mathbf{0}$ & 12 \\
\hline Estorno & 0 & -12 \\
\hline Resultado & 12 & -12 \\
\hline
\end{tabular}

Desta forma, conclui-se que o Estado de destino (B) é excessivamente onerado nessa hipótese. Nesse sentido, André Elali ${ }^{87}$ defende uma revisão desta situação, na medida em que "enquanto o primeiro [contribuinte] pôde se beneficiar com a incidência do ICMS em face do princípio da origem, o segundo é que terá de pagar ao exportador um crédito em face da atividade imune".

Outro problema das operações interestaduais, que também arrisca comprometer a integridade da Federação, é a substituição da operação interestadual por uma operação de importação.

Como já mencionado neste trabalho, a importação é tributada, pois, para o comércio internacional adotou-se o princípio do destino, diferente das operações interestaduais às quais foi adotado um misto de destino e origem.

Desta forma, analisando toda a lógica até agora explicada, conclui-se que, mais vantajoso é para um Estado fomentar a importação de um bem ou serviço para arrecadar a alíquota cheia do ICMS, do que aceitar que estes bens sejam adquiridos de outros Estados da federação, circunstância em que arrecadará apenas a parcela do imposto correspondente à alíquota interestadual.

Portanto, pode-se afirmar que as operações interestaduais promovem diversas distorções na arrecadação dos Estados, possibilitam a guerra fiscal e impossibilitam que exista neutralidade ${ }^{88}$ na tributação sobre o consumo.

87 ELALI, André. O federalismo fiscal brasileiro e o sistema tributário nacional. São Paulo: MP Editora, 2005, p. 75.

88 Sobre o assunto é válido citar o pensamento de Misabel Derzi: "O interesse em um imposto plurifásico, não cumulativo e neutro é considerado ideal em economias que tendem à integra- 
•• Tributação, direitos fundamentais e desenvolvimento

\subsection{Consequências da tributação interestadual no desenvolvimento regional}

A tributação interestadual do imposto sobre circulação de mercadorias e serviços é um dos assuntos mais questionáveis do sistema tributário vigente, em razão dos perversos efeitos que as distorções da atual sistemática vêm produzindo e dos poderosos interesses ligados à questão.

Conforme explanado ao longo do trabalho, a sistemática então vigente foi concebida à época da implantação do imposto sobre circulação de mercadorias [ICM], criado pela reforma tributária de 1967, na tentativa de mediação de conflitos decorrentes da repartição da receita do tributo oriunda das operaçôes interestaduais. Foi a partir da Emenda Constitucional n. 18/65 que os conflitos interestaduais se reconfiguraram utilizando o novo tributo para atrair indústrias ou outras atividades produtivas, mediante a concessão de estímulos ou incentivos, que acabaram por consolidar um clima de aberta concorrência entre os Estados.

Frente a essa postura adotada pelos entes federativos, foi promulgada a Emenda Constitucional n. $01 / 69$, que incluía o $\$ 6^{\circ}$ ao artigo 23 , passando a exigir, nos termos de lei complementar, a celebração de convênios para a concessão e revogação de isenção de ICM. Inobstante, em 1975 publicou-se a Lei Complementar no. 24, como mais uma tentativa de solucionar essa postura não cooperativa entre os Estados.

Com isso, a concessão de incentivos fiscais de ICMS pelos Estados, sem a celebração de convênio, e, pois, sem a deliberação do CONFAZ, objetivando a atração de investimentos, configura ilícito desde 1975. Entretanto, somente nos anos 90 este fenômeno se intensificou.

Para Marcos Nóbrega ${ }^{89}$ alguns pontos podem ser considerados para entender o crescimento da guerra fiscal na última década. Segundo o autor, um primeiro

ção, como nos modelos europeus ou latinos americanos. Ser neutro significa tanto ser indiferente na competitividade e concorrência, quanto na formação de preços de mercado. Ao mesmo tempo em que se adapta às necessidades de mercado, onerando o consumo e nunca produção ou o comércio, o ICMS (...) é plurifásico e oferece maiores vantagens ao fisco, pois antecipa o imposto que seria devido apenas no consumo, além de colocar todos os agentes econômicos das diversificadas etapas de circulação como responsáveis pela arrecadação (...)" (DERZI, Misabel Abreu Machado. Aspectos essenciais do ICMS como imposto de mercado. In: SCHOUERI, Luís Eduardo; ZILVETTI, Fernando Aurélio (Coord.). Direito tributário: estudos em homenagem a Brandão Machado. São Paulo: Dialética, 1998, p. 127).

89 Cf. NÓBREGA, Marcos. Renúncia de Receita: guerra fiscal e tax expenditure: uma abordagem do art. 14 da LRF. Disponível em: <http://www.eclac.org/ilpes/noticias/paginas/6/13526/ marcosnobrega1.pdf $>$. Acesso em: 10 nov. 2017. 
ponto relevante foi a efetiva ausência de uma política industrial e, sobretudo, regional. A política tributária dos Estados, por intermédio da concessão de incentivos de ICMS, passou a fazer às vezes de uma política de fomento industrial inexistente, acarretando uma competição desordenada e o aumento da concentração industrial em vez de minorá-la - os pequenos Estados, já combalidos em suas finanças, tiveram que conceder, proporcionalmente, mais incentivos para a atração de investimentos, tendo que para isso até mesmo que desconsiderar o retorno dos destes a sua economia.

Complementando seu entendimento, Nóbrega ${ }^{90}$ defende que outro pano de fundo do processo gerador desse comportamento foi o aumento, concedido pela Constituição de 1988, dos recursos destinados para Estados e Municípios. Apesar de, à primeira vista, parecer paradoxal, posto que mais recursos, por si, não seriam um fator indutor, isso ocorreu porque, para compensar a maior quantidade de recursos destinadas aos entes subnacionais, o Governo Federal implementou uma série de açôes, como o Fundo Social de Emergência ${ }^{91}$ e o Plano Real ${ }^{92}$, visando a redução dos recursos para esses entes.

No mesmo sentido, Fernando Rezende ${ }^{93}$ sustenta que, outro fator determinante ao agravamento da competitividade regional foram as regras estabelecidas na

90 NÓBREGA, Marcos. Ibidem.

91 "A centralização tributária esteve presente em outra medida importante, já citada, que foi o Fundo Social de Emergência (FSE), o qual reteve 20\% dos recursos dos Fundos de Participação nos cofres da União. O FSE teria validade provisória, mas foi posteriormente prorrogado e alterado o seu nome para Fundo de Estabilização Fiscal (FEF), mostrando que o executivo federal não precisava mais esconder o verdadeiro propósito desta medida. Mais do que a alocação em si dos recursos, a aprovação do Fundo Social de Emergência teve uma importância simbólica reveladora: foi a primeira vez que a União teve uma vitória tributária contra o estado desde o início da redemocratização. Isso abriu politicamente as portas para alteraçōes federativas no plano tributário, como a lei Kandir, embora ainda não permitisse estabelecer um novo desenho tributário à Federação brasileira, cuja feição continua fortemente descentralizadora em comparação aos principais países federativos do mundo" (ABRUCIO, Fernando. O longo caminho das reformas nos governos estaduais: crise, mudanças e impasses. Mimeo, p. 21).

92 Para Fernando Rezende, a política macroeconômica de estabilização da moeda com a implantação do Plano Real configurou "um golpe pesado na autonomia dos governos subnacionais com consequências políticas importantes", bem assim o processo de abertura internacional da economia, somada à "incapacidade do governo federal de tratar dos desequilíbrios regionais" (REZENDE, Fernando; AFONSO, José Roberto. A federação brasileira: fatos, desafios e perspectivas, 2002, pdf).

93 REZENDE, Fernando; AFONSO, José Roberto. Ibidem, p. 48. 
•• Tributação, direitos fundamentais e desenvolvimento

Lei de Responsabilidade Fiscal (Lei Complementar n. 101/2000). O autor reconhece que as novas regras, ao disciplinarem princípios e mandamentos constantes dos artigos 157 e 169 da Constituição, acabaram por implantar "a disciplina fiscal, a fim de evitar problemas macroeconômicos, acarretou restriçōes maiores à despesa, de tal modo que o orçamento, um instrumento dos mais importantes para o exercício do poder político nos Estados e Municípios, foi severamente afetado”.

Rezende ainda complementa que neste contexto de abertura econômica, estabilização da moeda e controle de despesas, foi criado um ambiente de livre movimento de capitais, principalmente estrangeiros, tanto para aquisições de empresas estatais em leilóes públicos, quanto em novos investimentos privados. Assim, essa intensificação de investimentos estrangeiros deflagrou uma competição acirrada entre os Estados brasileiros para atrair melhores projetos, sendo que a concessão de benefícios fiscais e concessões financeiras representam o principal instrumento desta competição por investimentos, fenômeno denominado "Guerra Fiscal".

Consoante às explicações já aqui tecidas, atualmente, a distribuição da receita do ICMS, proveniente das operações interestaduais, está calcada na adoção de alíquotas reduzidas sobre tais operações, no sentido de haver uma repartição da titularidade do produto arrecadado entre os chamados estados "produtores" e "consumidores", consolidando, assim, um princípio misto de incidência na origem e no destino, que intensifica a questão da guerra fiscal.

O modelo atual vem sendo questionado pelo Executivo dos Estados "consumidores", que, comumente, são os menos desenvolvidos. A principal alegação é a de que o regime que hoje rege a tributação interestadual, que implica em cobrança parcial do ICMS em favor do estado exportador nas operaçôes interestaduais, contribui para o agravamento das desigualdades regionais de renda, uma vez que provoca uma transferência de receita dos Estados basicamente consumidores para os Estados produtores.

Os Estados (origem) ao concederem um incentivo integral de ICMS atraem as empresas ao seu território, contudo essas empresas têm a maior parte de seus mercados em outro Estado (destino). Desta forma, quando da operação interestadual o contribuinte do Estado de destino pode reivindicar crédito pelo imposto supostamente arrecadado na origem, o peso financeiro imediato desses benefícios é suportado, de fato, pelo Estado onde o bem é consumido ${ }^{94}$.

94 REZENDE, Fernando; AFONSO, José Roberto. A federação brasileira: fatos, desafios e perspectivas, 2002, p. 46. 
Ives Gandra Martins ${ }^{95}$ defende que estes incentivos fiscais não onerosos, ou outorgados a "custo zero", não causam nenhum impacto negativo sobre o orçamento, como a possível redução de receitas, uma vez que acabam "implicando desenvolvimento da região e futuro crescimento da arrecadação, em face da geração de empregos e outros fatores de progresso decorrentes da estimulação fiscal concedida".

Nesse mesmo sentido, Marcos Nóbrega ${ }^{96}$ argumenta que a concessão de incentivos não parece ser, numa análise superficial, tão ruim. Afirma o autor que, apesar de a indústria incentivada não recolher o imposto, incentiva o "surgimento de empresas - satélites que pagarão ICMS, além do aumento do nível de emprego na região, gerando renda e em consequência aumentando a arrecadação pela venda de bens e serviços". Pois, toda indústria instalada em um Estado em razão de benefício fiscal, apesar de em sua atividade não gerar receita de ICMS, no caso de desoneração total, gera ao Estado no qual se instala, arrecadação de receitas, via fundo de participação, de arrecadação federal de Imposto de Renda e de Imposto sobre Produtos Industrializados, nos termos do artigo 159, I, da Constituição Federal.

Contudo, embora apresente pontos positivos à economia do Estado concedente do benefício tributário, a concessão indiscriminada e ilegal de incentivos fiscais compromete não só a economia do Estado que suporta o ônus do crédito legalmente inexistente, mas também toda organização federativa dos Estados.

Grande parte dos autores argumenta que um dos efeitos negativos de uma competição tributária é que ela tende a se generalizar, já que o setor privado, em busca de menores custos, tende a exigir que o governo estadual conceda incentivo fiscal semelhante aos existentes em outros Estados da federação, sob pena de mover-se ao Estado incentivador.

Com isso, todos os Estados se envolvem na "guerra fiscal", o que aumenta os conflitos na federação e reduz cada vez mais os incentivos. Neste estágio do conflito, os Estados menos desenvolvidos não conseguem competir em igualdade de condiçôes com os Estados desenvolvidos e acabam perdendo a disputa por investimento, aumentando ainda mais as disparidades já existentes.

95 Cf. MARTINS, Ives Gandra. Incentivos onerosos e não onerosos na lei de responsabilidade fiscal. In: SCAFF, Fernando Facury; CONTI, José Maurício (Coord.). Lei de responsabilidade fiscal. 10 anos de vigência. Questôes atuais. Florianópolis: Editora Conceito, 2010.

96 Cf. NÓBREGA, Marcos. Renúncia e receita: guerra fiscal e tax expenditure: uma abordagem do art. 14 da LRF. Disponível em: https://www.cepal.org/ilpes/noticias/paginas/6/13526/ marcosnobrega1.pdf. Acesso em: 10 nov. 2017. 
•• Tributação, direitos fundamentais e desenvolvimento

Ademais, como lembra André Elali97, no Brasil, a "guerra fiscal” é um ilícito. Não se trata de mera concessão de incentivos fiscais pelos Estados-membros, implica também em desrespeito ao "que determina a Constituição Federal, que prevê mecanismos de "harmonização".

A própria Constituição Federal determina que esses incentivos estejam sujeitos a aprovação do CONFAZ, o que gera mais um entrave, uma vez que a redução de alíquota abaixo do limite mínimo só é possível mediante a autorização da unanimidade dos Estados presentes e, evidente que muitas vezes o Estado que está ali representado não tem interesses ou possui interesses contrários à instalação dessa suposta empresa naquele outro Estado que concederia o benefício.

Nesse sentido, Rui Affonso ${ }^{98}$ argumenta que, a razão para estas concessões unilaterais de incentivos fiscais, da mesma forma, em completo desrespeito à Lei Complementar n. 24/75, reside também na "utilização indiscriminada do poder de veto de cada unidade federada como moeda de troca".

Desta forma, diante da dificuldade em obter essa aprovação do CONFAZ, os Estados acabam concedendo os benefícios fiscais mesmo que de maneira irregular, desencadeando reflexos normativos e infracionais em âmbito nacional, bem como prejudicando diretamente os contribuintes - tanto os que aceitam o incentivo fiscal que não foi aprovado por convênio, quanto os que recebem a mercadoria proveniente deste contribuinte que recebeu o incentivo fiscal.

Isso porque, o artigo $8^{\circ}$ da Lei Complementar $n^{\circ}$. 24/75, na hipótese de uma concessão unilateral de incentivo fiscal, prescreve sanção cumulativa de nulidade do ato que concede o benefício - a exigência do tributo não cobrado ou devolvido, a ineficácia do crédito fiscal atribuído ao contribuinte de destino e a ineficácia de uma lei ou ato do Estado de origem que conceda a remissão do débito, são exemplos de sanções aplicáveis a essa hipótese.

Observa-se que são medidas que recaem diretamente sobre o contribuinte, que, mesmo já tendo efetuado o pagamento do imposto nos moldes estipulados pelo Estado concessor do benefício, será detentor de um crédito fiscal ineficaz, sendo, portanto, compelido a pagar o valor que de fato deveria ter sido pago, como se não houvesse sido concedido qualquer incentivo.

ELALI, André. O federalismo fiscal brasileiro e o sistema tributário nacional. São Paulo: MP Editora, 2005.

98 AFFONSO, Rui. A crise da federação no Brasil. Ensaios FEE, Porto Alegre, v. 15, n. 2, 1994, p. 324-325. 
Frisa-se que essa postura ilegal adotada não gera apenas prejuízos regionais e meramente econômicos (perda das empresas que migraram). Por tratar-se de uma Federação, vislumbram-se, também, consequências diretas no âmbito administrativo e judiciário que repercutem em todo o cenário nacional.

\section{CONCLUSÃO}

O federalismo busca garantir, através da diversidade existente entre seus entes, uma unidade em completo respeito às normas previstas na Constituição Federal. Ainda que não haja um modelo ideal, abstrato, aplicável a toda gama de federaçôes existentes, uma vez que cada ordenamento jurídico estabelece as especificidades sobre sua forma de organização, em regra, uma Federação constitui uma forma de Estado constitucionalmente descentralizada, composta por uma pluralidade de entidades políticas dotadas de autonomia e que se auto organizam dentro dos limites legais impostos por sua Constituição.

A autonomia é, assim, conceito jurídico que pressupõe o exercício de direito próprio pelos entes federados. Ou seja, respeitados os princípios e repartiçōes de competências constitucionais, os Estados têm direito de elaborar e aprovar sua própria legislação, sem que haja um controle prévio pelo governo central.

No âmbito da competência tributária aos Estados foi atribuída a competência para instituir o Imposto sobre Operaçôes Relativas à Circulação de Mercadorias e Prestação de Serviços de Transporte Interestadual e Intermunicipal e de Comunicação, conhecido como ICMS.

Por tratar-se de tributo plurifásico e não cumulativo, com repartição de sua arrecadação entre os Estados quando em operações interestaduais, possui feição nacional, fazendo com que qualquer medida adotada unilateralmente por um Estado repercuta por todo o território nacional.

Desta forma, é necessário que haja uma série de limitações à capacidade legislativa destes entes políticos para que seja alcançada uma uniformização e afastada a amplificação das desigualdades econômicas já existentes nas diferentes regiōes do país.

A instituição de leis complementares, de resoluções pelo Senado Federal e, bem como, a celebração de convênios regulando a concessão de benefícios fiscais pelos entes são, hoje, os principais mecanismos que objetivam afastar o arbítrio na esfera regional, com vistas a uma plena integração nacional. 
-. Tributação, direitos fundamentais e desenvolvimento

Diante do exposto, concluiu-se que embora o ordenamento jurídico não vede a concessão de incentivos fiscais de ICMS pelos Estados, estes só poderão ser concedidos se forem obedecidos os parâmetros constitucionais referentes à competência tributária, à competência regulamentar, às leis complementares e desde que previstos como instrumento para execução de um plano de desenvolvimento nacional.

Logo, a adoção de atitudes unilaterais para a concessão de isenções e incentivos fiscais constituiu em qualquer hipótese, ofensa ao pacto federativo na medida em que afeta a economia de outros Estados e configura desrespeito à regra específica da Constituição Federal, que condiciona esta concessão à deliberação dos Estados na forma como prevê a Lei Complementar.

Contudo, evidente a complexidade normativa que envolve a questão, bem como o flagrante descumprimento pelos Estados da própria Constituição Federal, demonstrando que a origem da Guerra Fiscal não está na estrutura normativa em si, mas no seu descumprimento pelo órgão estatal que costumeiramente adota uma postura claramente anti-cooperativa e em completa desobediência aos princípios federalistas.

\section{REFERÊNCIAS}

ALEXANDRE, Ricardo. Direito tributário esquematizado. 9. ed. rev., atual. e ampl. Rio de Janeiro: Forense; São Paulo: Método, 2015.

AMARAL, Antonio Carlos Rodrigues do. O imposto sobre o valor agregado. São Paulo: Editora Rumo, 1995.

AMARO, Luciano. Direito tributário brasileiro. 21. ed. São Paulo: Saraiva, 2016.

ATALIBA, Geraldo. Constituição e Constituinte: regime federativo. São Paulo: RT, 1987. ATALIBA, Geraldo. Hipótese de incidência tributária. 6. ed. São Paulo: Malheiros, 2006. ATALIBA, Geraldo. Princípio federal, rigidez constitucional e Poder Judiciário. In: Estudos de Direito Tributário, São Paulo, 1980.

ATALIBA, Geraldo. Eficácia dos Convênios para Isenção do ICM. Revista de Direito Tributário, São Paulo: RT, n. 11 e 12, 1980.

BECKER, Alfredo Augusto. Teoria geral do direito tributário. 4. ed. São Paulo: Noeses, 2007.

BONILHA, Paulo Celso Bergstrom. IPI e ICM. Fundamentos da técnica não cumulativa. São Paulo: Resenha Tributária, 1979.

BORGES, José Souto Maior. Sobre as isençōes, incentivos e benefícios fiscais relativos ao ICMS. Revista Dialética de Direito Tributário, São Paulo: Dialética, n. 6, 1996. 
BRANDÃO JUNIOR, Salvador Cândido. Federalismo e ICMS: Estados-membros em "guerra fiscal". São Paulo: USP - Faculdade de Direito, 2013.

BRASIL. Lei n. 5.172, de 25 de outubro de 1966. Institui o Código Tributário Nacional. Diário Oficial [da] República Federativa do Brasil, Brasília, 27 out. 1966. Disponível em:<http://www2.planalto.gov.br/>.

BRASIL. Presidência da República. Constituição (1988). Emenda Constitucional n. 18, de 01 de dezembro de 1965. Reforma do Sistema tributário. Disponível em: <http://www. planalto.gov.br/ccivil_03/Constituicao/Emendas/Emc_anterior1988/emc18-65.htm>.

BRASIL. Presidência da República. Constituição (1988). Emenda Constitucional n. 01, de 17 de outubro de 1969. Edita o novo texto da Constituição Federal de 24 de janeiro de 1967. Disponível em: <http://www.planalto.gov.br/ccivil_03/Constituicao/Emendas/ Emc_anterior1988/emc01-69.htm>

BRASIL. Constituição (1934) Constituição da República dos Estados Unidos do Brasil. Rio de Janeiro, 1934. Disponível em: <http://www.planalto.gov.br/ccivil_03/Constituicao/ Constitui\%C3\%A7ao34.htm>

BRASIL. Constituição (1946) Constituição dos Estados Unidos do Brasil. Rio de Janeiro, 1946. Disponível em: <http://www.planalto.gov.br/ccivil_03/Constituicao/Constitui\% C3\%A7ao46.htm>.

BRASIL. Constituição (1967) Constituição da República Federativa do Brasil. Brasília, 1967. Disponível em: <http://www.planalto.gov.br/ccivil_03/Constituicao/Constitui\%C3\% A7ao67.htm>.

BRASIL. Constituição (1967) Emenda Constitucional n.1, de 24 de janeiro de 1969. Brasília, 1969. Disponível em: <http://www.planalto.gov.br/ccivil_03/Constituicao/Emendas/ Emc_anterior1988/e mc01-69.htm >.

BRASIL. Constituição (1988) Constituição da República Federativa do Brasil. 40. ed. São Paulo: Saraiva, 2007.

BRASIL. Lei Complementar n. 24, de 7 de janeiro de 1975. Dispõe sobre os convênios para a concessão de isenções do imposto sobre operações relativas à circulação de mercadorias, e dá outras providencias. Disponível em: <www.planalto.gov.br/ccivil_03/leis/LCP/ Lcp24.htm>

BRASIL. Lei Complementar n. 87, de 13 de setembro de 1996. Dispóe sobre o imposto dos Estados e do Distrito Federal sobre operações relativas à circulação de mercadorias e sobre prestações de serviços de transporte interestadual e intermunicipal e de comunicação, e dá outras providências. (LEI KANDIR). Disponível em: <www.planalto.gov.br/ccivil_03/ leis/LCP/Lcp87.htm>

CARVALHO, Paulo de Barros. Direito tributário: fundamentos jurídicos da incidência. 5. ed. São Paulo: Saraiva, 2007.

CARVALHO, Paulo de Barros. A concessão de isenções, incentivos ou benefícios fiscais no âmbito do ICMS. In: MARTINS, Ives Gandra da Silva; CARVALHO, Paulo de 
•• Tributação, direitos fundamentais e desenvolvimento

Barros (Coord.). Guerra fiscal. Reflexões sobre a concessão de benefícios fiscais no âmbito do ICMS. São Paulo: Noeses, 2012.

CARVALHO, Paulo de Barros. Curso de direito tributário. 23. ed. São Paulo: Saraiva, 2010. CARRAZZA, Roque António. Curso de direito constitucional tributário. 27. ed. São Paulo: Saraiva, 2011.

CARRAZZA, Roque António. ICMS. 14. ed. São Paulo: Malheiros, 2009.

CARRAZZA, Roque António. Convênios ICMS e art. 14 da lei de responsabilidade fiscal - sua inaplicabilidade - questôes conexas. Revista de Estudos Tributários, Porto Alegre, n. 16, 2000.

CASSEB, Paulo A. Federalismo. Aspectos contemporâneos. São Paulo: Juarez de Oliveira, 1999 (Coleção saber jurídico).

CAVALCANTI, Amaro. Regime federativo e a República brasileira. Brasília: Universidade de Brasília, 1983 (Coleção Temas brasileiros).

CONTI, José Maurício. Federalismo fiscal e fundos de participação. São Paulo: Juarez de Oliveira, 2001.

CONTI, José Maurício. Federalismo fiscal e reforma tributária: utopia ou realidade? In: SCHOUERI, Luís Eduardo (Coord.). Direito tributário. Homenagem a Paulo de Barros Carvalho. São Paulo: Quartier Latin, 2008.

CONVÊNIOS ICMS. In: CONFAZ, Ministério da fazenda. Disponível em: <https:// www.confaz.fazenda.gov.br/legislacao/convenios> Acesso em: 9 nov. 2017.

COSTA, Alcides Jorge. ICM na Constituição e na lei complementar. São Paulo: Resenha Tributária, 1978.

COSTA, Alcides Jorge. ICMS - natureza jurídica da isenção - natureza jurídica e função do convênio no âmbito do ICMS. In: Estudos sobre IPI, ICMS e ISS. São Paulo: Dialética, 2009.

DERZI, Misabel Abreu Machado. Distorções do princípio da não cumulatividade no ICMS - comparação com o IVA Europeu. In: I Congresso Nacional da Associação Brasileira de Direito Tributário, Belo Horizonte: Del Rey, 1998.

DERZI, Misabel Abreu Machado. Aspectos essenciais do ICMS como imposto de mercado. In: SCHOUERI, Luís Eduardo; ZILVETTI, Fernando Aurélio (Coord.). Direito tributário: estudos em homenagem a Brandão Machado. São Paulo: Dialética, 1998.

ELALI, André. O federalismo fiscal brasileiro e o sistema tributário nacional. São Paulo: MP Editora, 2005.

FERNANDES, Bernardo Gonçalves. Curso organização do Estado - Direito constitucional. Disponível em: https://pt.slideshare.net/LarissaMenandro/direito-constitucional-bernardofernandes . Acesso em: 21 nov. 2017 
FERREIRA FILHO, Manoel Gonçalves. Curso de direito constitucional. 38. ed. São Paulo: Saraiva, 2012.

LENZA, Pedro. Direito constitucional esquematizado. 18. ed. rev., atual. e ampl. São Paulo: Saraiva, 2014.

MARTINS, Ives Gandra da Silva. Estímulos Fiscais no ICMS e a unanimidade constitucional. In: Concessão de Benefícios Fiscais no âmbito do ICMS. São Paulo: Noeses, 2012.

MARTINS, Ives Gandra da Silva. O princípio da não cumulatividade. In: MARTINS, Ives Gandra da Silva (Coord.). O princípio da não cumulatividade. São Paulo: Revista dos Tribunais, 2004, n. 10, Nova Série.

MENDES, Marcos. Federalismo fiscal. In: BIDERMAN, Ciro; ARVATE, Paulo. Economia do setor Público no Brasil. Rio de Janeiro: Elsevier, 2004.

MIRANDA, Jorge. Teoria do Estado e da Constituição. 3. ed. Rio de Janeiro: Forense, 2011.

NÓBREGA, Marcos. Renúncia de Receita: guerra fiscal e tax expenditure: uma abordagem do art. 14 da LRF. Disponível em: <http://www.eclac.org/ilpes/noticias/paginas/6/13526/ marcosnobregal.pdf>. Acesso em: 10 nov. 2017.

PAULSEN, Leandro; DE MELO, José Eduardo Soares. Impostos Federais, Estaduais e Municipais. 6. ed. rev. e atual. Porto Alegre: Livraria do Advogado, 2011.

REVERBEL, Carlos Eduardo Dieder. O federalismo numa visão tridimensional do direito. Porto Alegre: Livraria do Advogado, 2012.

REZENDE, Fernando; AFONSO, José Roberto. A federação brasileira: fatos, desafios e perspectivas, 2002.

SCHOUERI, Luis Eduardo. Direito tributário. 6. ed. São Paulo: Saraiva, 2016.

SILVA, José Afonso. Curso de direito constitucional positivo. 25. ed. São Paulo: Malheiros, 2005.

SILVA, José Afonso. Federalismo e autonomias no estado brasileiro: federalismo nominal e federalismo de regiōes. In: I Simposium Internacional de Derecho Constitucional Autonómico. Espanha: Generalitat Valenciana, 1985.

TORRES, Ricardo Lobo. Tratado de direito constitucional, financeiro e tributário. Rio de Janeiro: Renovar, 2005.

ZIMMERMANN, Augusto. Teoria geral do federalismo democrático. 2. ed. Rio de Janeiro: Lumen Juris, 2005. 
